Prepared in cooperation with the Standing Rock Sioux Reservation

\title{
Water, Bed-Sediment, and Fish-Tissue Quality within the Standing Rock Sioux Reservation, North Dakota and South Dakota, September 2006
}

Scientific Investigations Report 2007-5268 


\section{Water, Bed-Sediment, and Fish-Tissue Quality within the Standing Rock Sioux Reservation, North Dakota and South Dakota, September 2006}

By William C. Damschen and Robert F. Lundgren

Prepared in cooperation with the Standing Rock Sioux Reservation

Scientific Investigations Report 2007-5268 


\title{
U.S. Department of the Interior DIRK KEMPTHORNE, Secretary
}

\author{
U.S. Geological Survey \\ Mark D. Myers, Director
}

\section{U.S. Geological Survey, Reston, Virginia: 2007}

For product and ordering information:

World Wide Web: http://www.usgs.gov/pubprod

Telephone: 1-888-ASK-USGS

For more information on the USGS — the Federal source for science about the Earth, its natural and living resources, natural hazards, and the environment:

World Wide Web: http://www.usgs.gov

Telephone: 1-888-ASK-USGS

Any use of trade, product, or firm names is for descriptive purposes only and does not imply endorsement by the U.S. Government.

Although this report is in the public domain, permission must be secured from the individual copyright owners to reproduce any copyrighted materials contained within this report.

Suggested citation:

Damschen, W.C., and Lundgren, R.F., 2007, Water, bed-sediment, and fish-tissue quality within the Standing Rock Sioux Reservation, North Dakota and South Dakota, September 2006: U.S. Geological Survey Scientific Investigations Report 2007-5268, 29 p. 


\section{Contents}

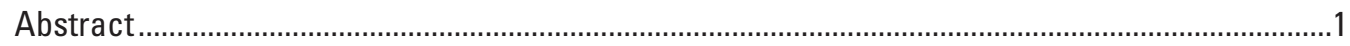

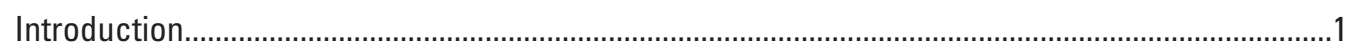

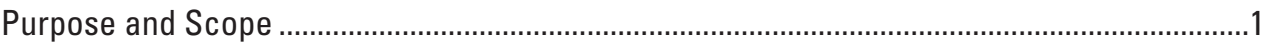

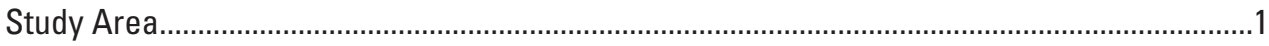

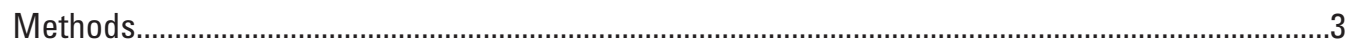

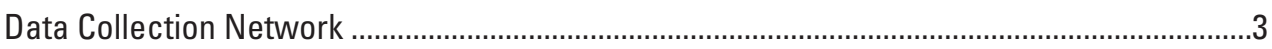

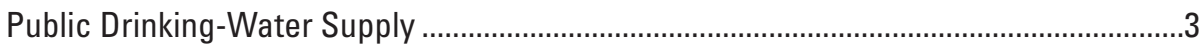

Solen Water-Delivery System ................................................................................

Selfridge Water-Delivery System ..........................................................................

Fort Yates Water-Delivery System ............................................................................

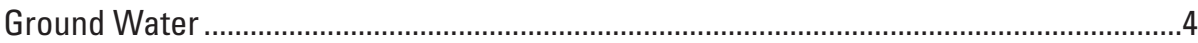

Surface Water and Bed Sediment ................................................................................. 4

Fish Tissue ................................................................................................................................

Established Water-Quality Standards and Health-Based Screening Levels....................................4

U.S. Environmental Protection Agency Maximum Contaminant Levels ......................................4

U.S. Environmental Protection Agency Secondary Maximum Contaminant Levels ................4

U.S. Environmental Protection Agency Health Advisories ......................................................4

U.S. Environmental Protection Agency Maximum Contaminant Level Goal..............................4

U.S. Geological Survey Health-Based Screening Levels......................................................... 4

U.S. Environmental Protection Agency Screening Values for Contaminants in Fish Tissue....5

Water, Bed-Sediment, and Fish-Tissue Quality ...........................................................................6

Major Inorganic and Minor and Trace Inorganic Constituents in Water .................................6

Volatile Organic Compounds in Water ....................................................................................6

Minor and Trace Inorganic Constituents in Bed Sediment.........................................................6

Minor and Trace Inorganic Constituents in Fish Tissue and Livers............................................6

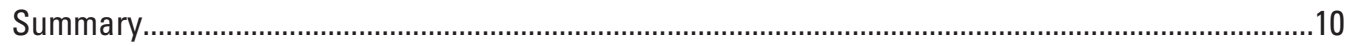

References Cited............................................................................................................................10

Supplement. Analytical data for water, bed sediment, and fish tissue within the

Standing Rock Sioux Reservation .................................................................................13

Tables:

1-1. Sample location information................................................................................14

1-2. Analytical results for samples collected from the Solen water-delivery system, Standing Rock Sioux Reservation, North Dakota .........................................16

1-3. Analytical results for samples collected from the Selfridge water-delivery system, Standing Rock Sioux Reservation, North Dakota ..........................................17

1-4. Analytical results for samples collected from the Fort Yates water-delivery system, Standing Rock Sioux Reservation, North Dakota ........................................18

1-5. Analytical results for samples collected from select ground-water sources, Standing Rock Sioux Reservation, North Dakota ......................................................22

1-6. Analytical results for samples collected from select surface-water and bed-sediment sources, Standing Rock Sioux Reservation, North and

South Dakota

1-7. Analytical results for fish-tissue and liver samples collected from the Missouri River near Fort Yates, North Dakota 


\section{Figures}

1. Maps shpwing locations of sample sites within the Standing Rock Sioux Reservation, North and South Dakota.

2-3. Graphs showing:

2. Major inorganic constituents in select public drinking-water sources, ground waters, and surface waters within the Standing Rock Sioux Reservation, North and South Dakota.

3. Minor and trace inorganic constituents in select public drinking-water sources, ground waters, and surface waters within the Standing Rock Sioux Reservation, North and South Dakota.

\section{Tables}

1. Summary of established water-quality standards and health-based screening levels for selected contaminants in water.....

2. Concentrations of minor and trace inorganic constituents in fish tissue and U.S. Environmental Protection Agency Screening Values for target species collected on the Missouri River near Fort Yates, North Dakota

\section{Conversion Factors and Datum}

\begin{tabular}{lcl}
\hline Multiply & By & To obtain \\
\hline mile (mi) & Length & \\
\hline & 1.609 & kilometer $(\mathrm{km})$ \\
\hline acre & Area & \\
\hline & 0.4047 & hectare (ha) \\
\hline gallon (gal) & Volume & liter $(\mathrm{L})$ \\
\hline & 3.785 & \\
\hline pound, avoirdupois (lb) & Mass & kilogram $(\mathrm{kg})$ \\
\hline
\end{tabular}

Temperature in degrees Celsius $\left({ }^{\circ} \mathrm{C}\right)$ may be converted to degrees Fahrenheit $\left({ }^{\circ} \mathrm{F}\right)$ as follows:

$$
{ }^{\circ} \mathrm{F}=\left(1.8 \times{ }^{\circ} \mathrm{C}\right)+32
$$

Specific conductance is given in microsiemens per centimeter at 25 degrees Celsius $(\mu \mathrm{S} / \mathrm{cm}$ at $\left.25^{\circ} \mathrm{C}\right)$.

Concentrations of chemical constituents in water are given either in milligrams per liter (mg/L) or micrograms per liter ( $\mu \mathrm{g} / \mathrm{L})$.

Horizontal coordinate information is referenced to the North American Datum of 1927 (NAD 27). 


\title{
Water, Bed-Sediment, and Fish-Tissue Quality within the Standing Rock Sioux Reservation, North Dakota and South Dakota, September 2006
}

\author{
By William C. Damschen and Robert F. Lundgren
}

Abstract

During September 2006, samples from public waterdelivery systems, ground water, surface water, bed-sediment, and fish-tissue sources were collected at 32 locations within the Standing Rock Sioux Reservation and analyzed to aid in the evaluation of any immediate water-quality concerns. Samples were collected from Solen, Selfridge, and Fort Yates, North Dakota, water-delivery systems and included raw water samples and treated water samples from water users on the water-delivery systems. Samples from the Solen and Selfridge systems were analyzed for dissolved major inorganic and dissolved minor and trace inorganic concentrations. Samples from the Fort Yates system were analyzed for dissolved major inorganic concentrations, dissolved minor and trace inorganic concentrations, total and dissolved nutrient concentrations, total and dissolved organic carbon concentrations, and volatile organic compound concentrations. Water samples were collected from ground-water wells throughout the reservation only in North Dakota and analyzed for dissolved major inorganic concentrations and dissolved minor and trace inorganic concentrations. Water samples were collected at locations on the Missouri River and its major tributaries within the reservation and analyzed for dissolved major inorganic concentrations and dissolved minor and trace inorganic concentrations; bed sediment was collected at these sites and analyzed for minor and trace inorganic concentrations. Fish-tissue and liver samples were collected from several species on the Missouri River near Fort Yates and analyzed for minor and trace inorganic concentrations. Results of the water-quality analysis revealed very little of concern, with the exception of elevated boron concentrations in the drinking water and ground water in the area of Selfridge and Solen and minor exceedences of total trihalomethanes in the Fort Yates water-delivery system.

\section{Introduction}

Tribal members of the Standing Rock Sioux Reservation are concerned about the quality of water from various sources on the reservation and that some of the drinking water consumed on the reservation is adversely affecting human health (Mni Sose Intertribal Rights Coalition, Inc, 2005). Water-quality data are needed to determine potential sources of poor water quality in water-delivery, surface-water, and ground-water supplies and to better understand possible links to health effects among tribal members; therefore, the U.S. Geological Survey (USGS) in cooperation with the Standing Rock Sioux Reservation developed a water-quality reconnaissance plan to investigate these concerns.

\section{Purpose and Scope}

This report provides a limited overview of the water, bed-sediment, and fish-tissue quality from select water sources within the reservation in an attempt to evaluate the overall quality of the water resources on the reservation. Analytical results were compared to established standards and screening values for drinking water, bed sediment, and fish tissue. Samples were collected within the reservation from September 11 through 23, 2006, and analyzed at the USGS National Water Quality Laboratory (NWQL) in Denver, Colorado.

\section{Study Area}

The reservation is in south-central North Dakota (Sioux County) and north-central South Dakota (Corson County) and has a total land area of 2.3 million acres (fig. 1). The area is fairly well drained and includes several small streams, lakes, 


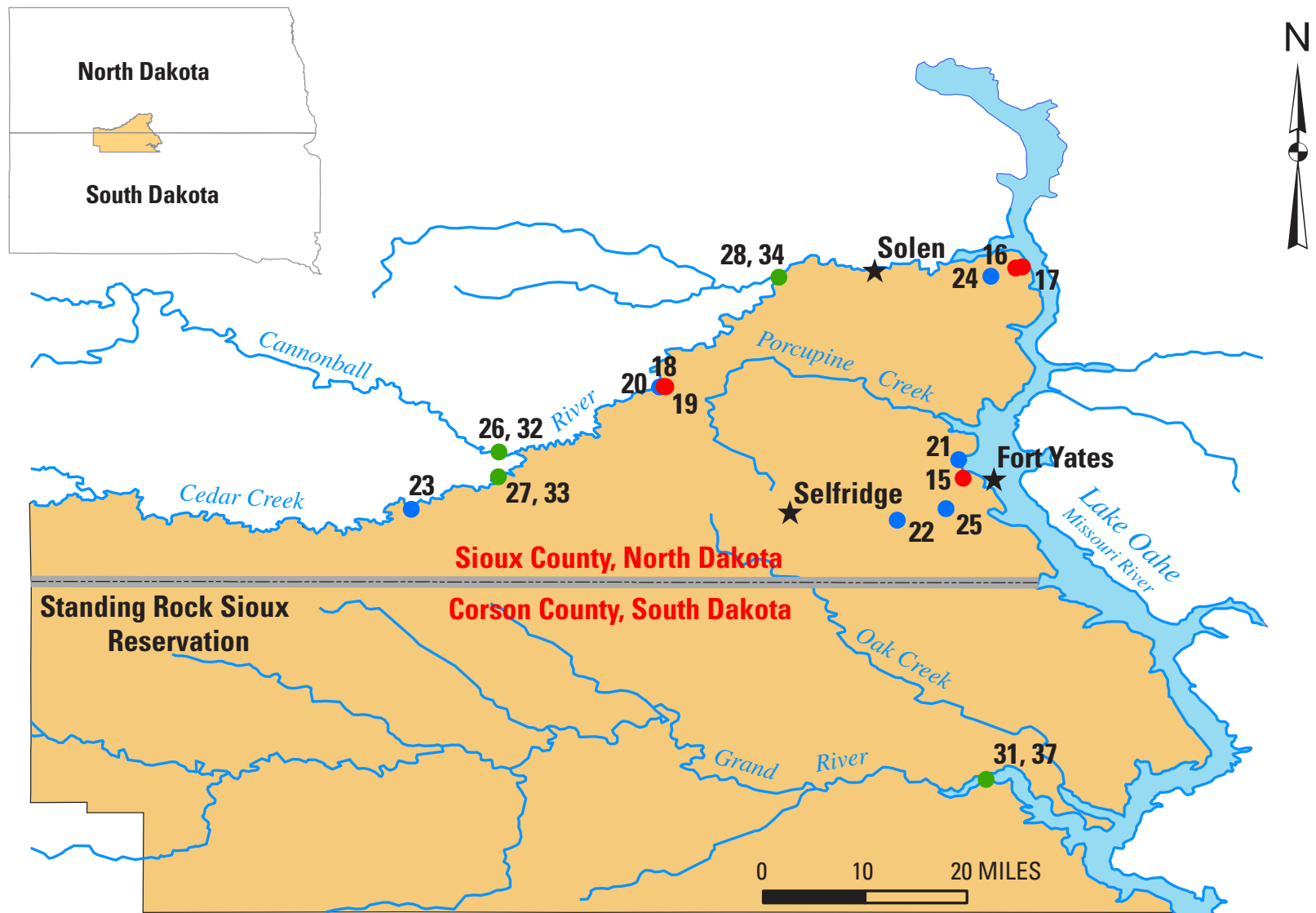

Base from U.S. Geological Survey digital data, 2005, 1:2,000,000 and North Dakota Department of Transportation, 2003, 1:24,000, GCS North American 1983

\section{Solen}

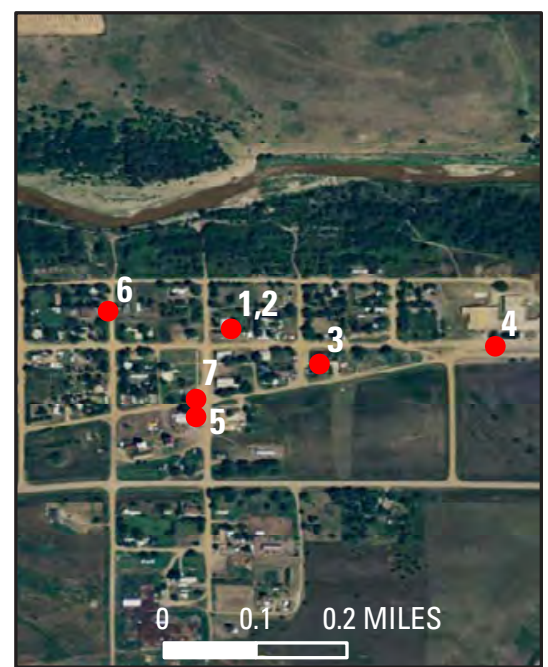

Fort Yates

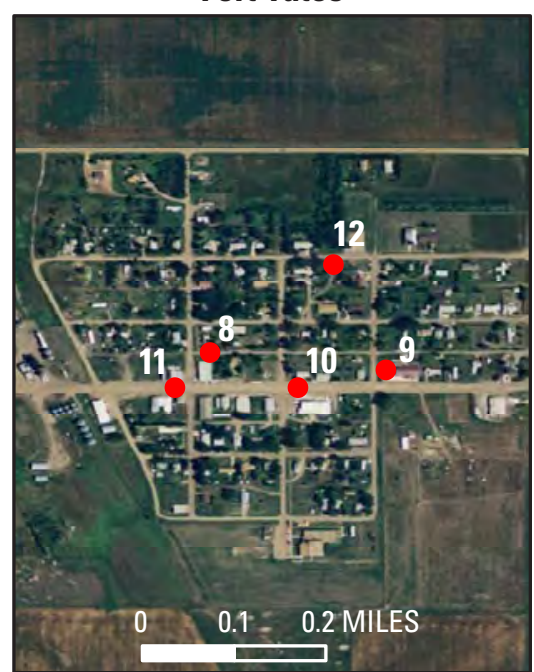

Selfridge

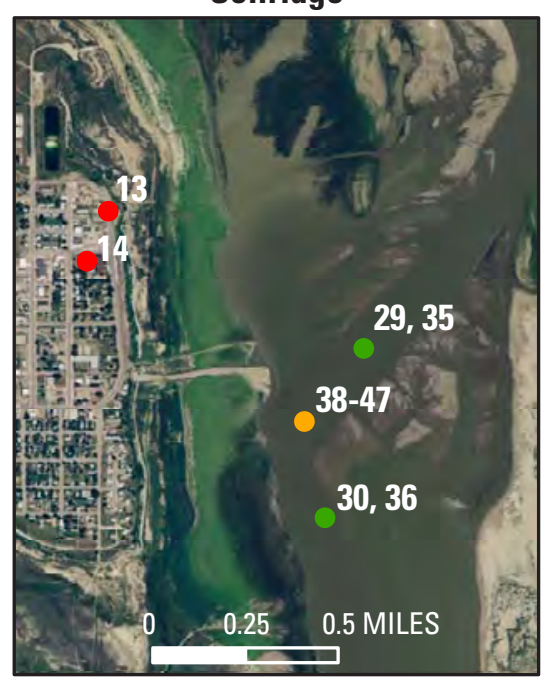

Base from U.S. Department of Agriculture Farm Service Agency NAIP, 2006, 1 meter,

Universal Transverse Mercator projection, Zone 14, North American Datum 1983

\section{EXPLANATION}

$\downarrow$ See insets for sampling locations within/near each town.

$0^{15}$ Water-delivery systems

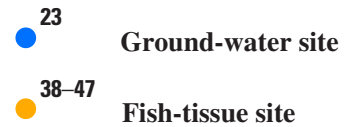

26, 32 Surface water and bed sediment-first number is surface water site; second number is bed-sediment site

Figure 1. Locations of sample sites within the Standing Rock Sioux Reservation, North and South Dakota. 
and dugouts. Surface water is the major water source for the reservation; the Missouri River provides the largest portion of the surface-water supply. Ground water is not as abundant as surface water and, where available, is usually adequate for only small-scale use (Howells, 1982). Shallow ground water is scarce and unreliable, and deep ground water, while generally more plentiful, is highly mineralized and of poor quality (http://www.mnisose.org/profiles/strock.htm). Surface and ground water on the reservation are used for municipal, domestic, stock-water, recreation, and irrigation purposes (Amundson, 2002).

\section{Methods}

Water-quality, bed-sediment, and fish-tissue samples were collected in North and South Dakota by USGS and Standing Rock Sioux Tribe Department of Water Resources personnel from September 11 through 23, 2006. The 32 locations where samples were collected are described in Supplement table 1-1.

Samples were collected according to U.S. Geological Survey protocols (U.S. Geological Survey, variously dated) and were analyzed at the NWQL utilizing analytical methods for constituent groups described in the following publications:

- Major inorganic and minor trace inorganic constituents in water (American Public Health Association, 1998; Faires, 1993; Fishman, 1993; Fishman and Friedman, 1989; Garbarino, 1999; Garbarino and others, 2006; Struzeski and others, 1996).

- Volatile organic compounds (Conner and others, 1998).

- Nutrients (Fishman, 1993; Patton and Truitt, 1992; Patton and Truitt, 2000).

- Minor and trace inorganic constituents in bed sediment (Arbogast, 1996; Briggs and Meier, 1999; Hageman, 2007, Taggart, 2002).

- Minor and trace inorganic constituents in fish tissue (U.S. Environmental Protection Agency, 1996; Garbarino and others, 2006; Hoffman, 1996).

Field quality assurance and quality control for the study described in this report were addressed by using the same data-collection procedures that are used in the USGS National Stream Quality Accounting Network (NASQAN) program (Kelly and others, 2001). Results for blank and replicate samples collected during 2006 for the NASQAN program in North Dakota indicate that no sample contamination was introduced by field activities (data on file at the USGS North Dakota Water Science Center, Bismarck, North Dakota).

\section{Data Collection Network}

Samples and results are grouped into the various categories as described in the following sections.

\section{Public Drinking-Water Supply}

\section{Solen Water-Delivery System}

Domestic water for Solen, North Dakota, is delivered by one public supply well located within the city. Water is treated at the well location and then distributed to the water users. Seven water samples were collected from the waterdelivery system: two samples from the supply well, one raw, untreated sample (Supplement table 1-2, sample 2) and one treated sample (Supplement table 1-2, sample 1); and five samples from users on the water-delivery system (Supplement table 1-2, samples 3-7). Water samples were analyzed for dissolved major inorganic and dissolved minor and trace inorganic concentrations.

\section{Selfridge Water-Delivery System}

Domestic water for Selfridge, North Dakota, is delivered from one public supply well located within the city. Water is treated at the well and then distributed to water users. One raw water sample was collected from the supply well (Supplement table 1-3, sample 8). Four water samples were collected from water users on the water-delivery system (Supplement table 1-3, samples 9-12). Water samples were analyzed for dissolved major inorganic and dissolved minor and trace inorganic concentrations.

\section{Fort Yates Water-Delivery System}

Domestic water for Fort Yates, North Dakota, and surrounding areas is delivered by the Missouri River intake treatment facility located within the city of Fort Yates. Missouri River water is pumped into the facility and treated, then delivered to the city of Fort Yates and surrounding areas through a pipeline. Seven water samples were collected from the delivery system. A raw water sample was collected at the water intake (Supplement table 1-4, sample 13), and six water samples were collected from water users on the delivery system (Supplement table 1-4, samples 14-19). Water samples were analyzed for dissolved major inorganic and dissolved minor and trace inorganic concentrations, total and dissolved nutrients, total and dissolved organic carbon, and volatile organic compounds (VOCs). 


\section{Ground Water}

Water samples were collected at six ground-water wells throughout the reservation within Sioux County, North Dakota (Supplement table 1-5, samples 20-25). Water samples were analyzed for dissolved major inorganic and dissolved minor and trace inorganic concentrations.

\section{Surface Water and Bed Sediment}

Water and bed-sediment samples were collected from six surface-water locations within the Missouri River drainage on the reservation in North and South Dakota. Water samples were analyzed for dissolved major inorganic and dissolved minor and trace inorganic concentrations (Supplement table 1-6, samples 26-31). Bed-sediment samples were analyzed for minor and trace inorganic concentrations (Supplement table 1-6, samples 32-37).

\section{Fish Tissue}

Fish-tissue samples were collected on the Missouri River near Fort Yates, North Dakota. Samples from each of 10 fish species were analyzed for minor and trace inorganic concentrations (Supplement table 1-7, samples 38-47). Additionally an individual minor and trace inorganic analysis was done on the livers of the larger species.

\section{Established Water-Quality Standards and Health-Based Screening Levels}

Under the authority of the Safe Drinking Water Act in 1974, the U.S. Environmental Protection Agency (USEPA) established a public drinking-water program. Under the act, the USEPA set limits for contaminant levels in drinking water to ensure the safety of public drinking water. Current 2007 water-quality standards are listed in table 1.

\section{U.S. Environmental Protection Agency Maximum Contaminant Levels}

The USEPA has set national water-quality standards for certain contaminants called Maximum Contaminant Levels (MCLs). MCLs are legally enforceable standards that set the maximum permissible level of a contaminant in water that is delivered to any user of a public water system. MCLs are set as close as feasible to the maximum level of a contaminant at which no known or anticipated adverse effects on human health would occur, taking into account the best available technology, treatment techniques, cost considerations, expert judgment, and public comments (U.S. Environmental Protection Agency, 2006a).

\section{U.S. Environmental Protection Agency Secondary Maximum Contaminant Levels}

In addition, the USEPA has established National Secondary Drinking Water Regulations that set non-mandatory water-quality standards for 15 contaminants. The USEPA does not enforce these Secondary Maximum Contaminant Levels (SMCLs). They are established only as guidelines to assist public water systems in managing their drinking water for aesthetic considerations, such as taste, color, and odor. These contaminants are not considered to present a risk to human health at the SMCL (U.S. Environmental Protection Agency, 1992).

\section{U.S. Environmental Protection Agency Health Advisories}

The USEPA health advisories are an estimate of acceptable drinking-water levels for a chemical substance based on health effects information. A health advisory is not a legally enforceable Federal standard, but serves as technical guidance to assist Federal, State, and local officials (U.S. Environmental Protection Agency, 2006b). The USEPA currently has 1-day, 10-day, and lifetime health advisories established to estimate the concentration of a chemical in drinking water that is not expected to cause any adverse noncarcinogenic effects.

\section{U.S. Environmental Protection Agency Maximum Contaminant Level Goal}

The USEPA Maximum Contaminant Level Goal (MCLG) is the level of a contaminant in drinking water below which there is no known or expected risk to health. MCLGs allow for a margin of safety and are non-enforceable public health goals (U.S. Environmental Protection Agency, 2006a).

\section{U.S. Geological Survey Health-Based Screening Levels}

Health-Based Screening Levels (HBSLs) are benchmark concentrations of contaminants in water that may be of potential concern for human health. HBSLs are non-enforceable guidelines that were developed by the USGS in collaboration with USEPA and others using USEPA methodologies and the most current, USEPA peer-reviewed, publicly available human-health toxicity information (Toccalino and others, 2003). The USGS and its cooperators are continuing to refine the HBSL methodology. 


\section{U.S. Environmental Protection Agency Screening Values for Contaminants in Fish Tissue}

USEPA screening values (SV) are defined as concentrations of target contaminants in fish or shellfish tissue that are of potential public health concern and used as threshold values against which levels of contamination in similar tissue collected from the ambient environment can be compared. Exceedance of these SVs should be taken as an indication that more intensive site-specific monitoring and/or evaluation of human health risk should be conducted (U.S. Environmental Protection Agency, 2000a).

Table 1. Summary of established water-quality standards and health-based screening levels for selected contaminants in water.

[USEPA MCL, U.S. Environmental Protection Agency Maximum Contaminant Level; USEPA SMCL, U.S. Environmental Protection Agency Secondary Maximum Contaminant Level; HBSL, Health-Based Screening Level developed by U.S. Geological Survey, USEPA, and others; NA, not available; mg/L, milligrams per liter; $\mu \mathrm{g} / \mathrm{L}$, micrograms per liter]

\begin{tabular}{|c|c|c|c|c|}
\hline Contaminant & Constituent type & USEPA MCL & $\begin{array}{l}\text { USEPA } \\
\text { SMCL }\end{array}$ & HBSL \\
\hline Aluminum & Minor and trace inorganic constituent & NA & $2 \mathrm{mg} / \mathrm{L}$ & NA \\
\hline Antimony & Minor and trace inorganic constituent & $6 \mu \mathrm{g} / \mathrm{L}$ & NA & NA \\
\hline Arsenic & Minor and trace inorganic constituent & $10 \mu \mathrm{g} / \mathrm{L}$ & NA & NA \\
\hline Barium & Minor and trace inorganic constituent & $2,000 \mu \mathrm{g} / \mathrm{L}$ & NA & NA \\
\hline Beryllium & Minor and trace inorganic constituent & $4 \mu \mathrm{g} / \mathrm{L}$ & NA & NA \\
\hline Boron & Minor and trace inorganic constituent & NA & NA & $1,000 \mu \mathrm{g} / \mathrm{L}$ \\
\hline Cadmium & Minor and trace inorganic constituent & $5 \mu \mathrm{g} / \mathrm{L}$ & NA & NA \\
\hline Chloride & Major inorganic constituent & NA & $250 \mathrm{mg} / \mathrm{L}$ & NA \\
\hline Chromium & Minor and trace inorganic constituent & $100 \mu \mathrm{g} / \mathrm{L}$ & NA & NA \\
\hline Copper & Minor and trace inorganic constituent & $1,300 \mu \mathrm{g} / \mathrm{L}$ & $1 \mathrm{mg} / \mathrm{L}$ & NA \\
\hline Fluoride & Major inorganic constituent & $4,000 \mu \mathrm{g} / \mathrm{L}$ & $2 \mathrm{mg} / \mathrm{L}$ & NA \\
\hline Iron & Minor and trace inorganic constituent & NA & $0.3 \mathrm{mg} / \mathrm{L}$ & NA \\
\hline Lead & Minor and trace inorganic constituent & $15 \mu \mathrm{g} / \mathrm{L}$ & NA & NA \\
\hline Manganese & Minor and trace inorganic constituent & NA & $0.05 \mathrm{mg} / \mathrm{L}$ & $300 \mu \mathrm{g} / \mathrm{L}$ \\
\hline Nickel & Minor and trace inorganic constituent & NA & NA & $100 \mu \mathrm{g} / \mathrm{L}$ \\
\hline Selenium & Minor and trace inorganic constituent & $50 \mu \mathrm{g} / \mathrm{L}$ & NA & NA \\
\hline Silver & Minor and trace inorganic constituent & NA & $0.1 \mathrm{mg} / \mathrm{L}$ & $100 \mu \mathrm{g} / \mathrm{L}$ \\
\hline Sulfate & Major inorganic constituent & NA & $250 \mathrm{mg} / \mathrm{L}$ & NA \\
\hline Total Trihalomethanes (TTHMs) & Volatile organic compound & $80 \mu \mathrm{g} / \mathrm{L}$ & NA & NA \\
\hline Zinc & Minor and trace inorganic constituent & NA & $5 \mathrm{mg} / \mathrm{L}$ & $2,000 \mu \mathrm{g} / \mathrm{L}$ \\
\hline
\end{tabular}




\section{Water, Bed-Sediment, and Fish-Tissue Quality}

Results for sample analyses can be found in Supplement tables 1-2 through 1-7. The results were compared to USEPA water-quality standards and USGS health-based screening levels for contaminants in drinking water, ground water, surface water, and fish tissue.

\section{Major Inorganic and Minor and Trace Inorganic Constituents in Water}

Concentrations of major inorganic and minor and trace inorganic constituents in the 31 water samples collected did not exceed MCLs (figs. 2 and 3); however, arsenic in ground water approached the MCL of $10 \mu \mathrm{g} / \mathrm{L}$ at 2 wells (Supplement table 1-5). Fluoride, manganese, and sulfate concentrations in some samples from the Solen and Selfridge water-supply systems and from ground-water sources exceeded the SMCLs. Long-term exposure to elevated fluoride concentrations may have potential health effects of flourosis ( U.S. Environmental Protection Agency, 1994). Higher concentrations of sulfate may have a laxative effect and give water a bitter taste.

Boron exceeded the HBSL of 1,000 $\mu \mathrm{g} / \mathrm{L}$. The USEPA does not have an MCL for boron but does have a lifetime health advisory (HA) of 1,000 $\mu \mathrm{g} / \mathrm{L}$ (U.S. Environmental Protection Agency, 2006a). The lifetime HA is based on exposure of a 70-kg adult consuming 2 liters of water per day. Several of the boron values for the Solen and Selfridge water systems and ground-water wells exceeded the HBSL and HA. Of the 18 samples collected at these sites, 16 samples exceeded the HBSL and HA of 1,000 $\mu \mathrm{g} / \mathrm{L}$. The highest value was 3,440 $\mu \mathrm{g} / \mathrm{L}$ (Supplement table 1-2, samples 2 and 7) and the lowest value was $183 \mu \mathrm{g} / \mathrm{L}$ (Supplement table 1-5, sample 25). Concentrations in the Solen samples ranged from $3,380 \mu \mathrm{g} / \mathrm{L}$ to $3,440 \mu \mathrm{g} / \mathrm{L}$. Boron occurs naturally in ground water; other sources include the atmospheric deposition of coal combustion products, storage or disposal of coal ash, and production of consumer and agricultural products such as fertilizer. Ingesting large amounts of boron can be a humanhealth concern (Agency for Toxic Substances and Disease Registry, 1992).

\section{Volatile Organic Compounds in Water}

Of the 29 regulated VOCs analyzed for the Fort Yates water-delivery system, the four trihalomethanes (trichloromethane $\left(\mathrm{CHCl}_{3}\right)$; bromodichloromethane $\left(\mathrm{CHBrCl}_{2}\right)$; dibromochloromethane $\left(\mathrm{CHBr}_{2} \mathrm{Cl}\right)$; and, tribromomethane $\left(\mathrm{CHBr}_{3}\right)$ were the most frequently detected VOCs in samples collected from water users on the delivery system. The relative concentrations of the four THMs in all six samples are expected in natural water that has a low bromide content (Ivahnenko and Barbash, 2004). In such waters, $\mathrm{CHCl}_{3}$ is expected to be the highest concentration, $\mathrm{CHBrCl}_{2}$ next largest, then $\mathrm{CHBr}_{2} \mathrm{Cl}$, and $\mathrm{CHBr}_{3}$ the lowest concentration. The sum of the total THMs (TTHM) for each of the six sites was 64, 64, 115, 85,92 , and $86 \mu \mathrm{g} / \mathrm{L}$, respectively. The sum of the concentrations in samples at four locations (Supplement table 1-4, samples 13-19) exceeded the MCL of $80 \mu \mathrm{g} / \mathrm{L}$ for TTHM (U.S. Environmental Protection Agency, 2006a). The presence of a free chlorine residual in the water being pumped into the distribution system during the September 2006 sampling period may explain the higher values (Ivahnenko and Zogorski, 2006). Until the free chlorine is removed or reduced to chloride, the THM reaction continues to form THMs, and water users at the end of a distribution may have the largest exposure (John Zogorski, U.S. Geological Survey, South Dakota Water Science Center, written commun., March 9, 2007).

The presence of trichloromethane in drinking water is a potential human-health concern. In 1986, the USEPA classified trichloromethane as a probable human carcinogen (Group B2 carcinogen) on the basis of evidence of its carcinogenicity in animals (U.S. Environmental Protection Agency, 2000b). In 1998, the USEPA revised the carcinogenicity risk assessment for trichloromethane, stating that the compound is likely to be carcinogenic to humans by all routes of exposure at concentrations high enough to cause cytotoxicity or the formation of regenerative nodules in susceptible tissues (U.S. Environmental Protection Agency, 2002). More recently, the USEPA revised the MCLG for trichloromethane to $70 \mu \mathrm{g} / \mathrm{L}$ on the basis of non-cancer effects (U.S. Environmental Protection Agency, 2004).

\section{Minor and Trace Inorganic Constituents in Bed Sediment}

Bed sediment collected at the surface-water sampling sites were analyzed for minor and trace inorganic constituents (Supplement table 1-6, samples 32-37). The available Federal sediment-quality screening values and standards are complex and apply to individual basins or regions other than the study area. Developing these screening values for this study area would require extensive information that is beyond the scope of this report. The North Dakota Department of Health is currently in the process of developing bed-sediment quality criteria for the State of North Dakota (Mike Ell, North Dakota Department of Health, oral commun., April 25, 2007) that can be used in the future for comparison to results in this report.

\section{Minor and Trace Inorganic Constituents in Fish Tissue and Livers}

The 10 fish-tissue samples were analyzed for 22 minor and trace inorganic constituents (Supplement table 1-7, samples 38-47). Results for four constituents that are of human health concern (arsenic, cadmium, mercury, and 
selenium) were compared to SVs for this study (table 2). Of the 10 species collected only the northern pike, channel catfish, common carp, and yellow perch are considered recommended target species for inland fresh waters by the USEPA screening criteria (U.S. Environmental Protection Agency, 2000a). Target species are species that are commonly consumed in the study area and are of commercial, recreational, or subsistence value. Even though the common carp is not a popular game fish, the USEPA recommends it as a target species because it is a bottom feeder. Bottom-feeding species such as channel catfish and common carp have been used extensively to monitor a wide variety of containments (U.S. Environmental Protection Agency, 2000a). None of
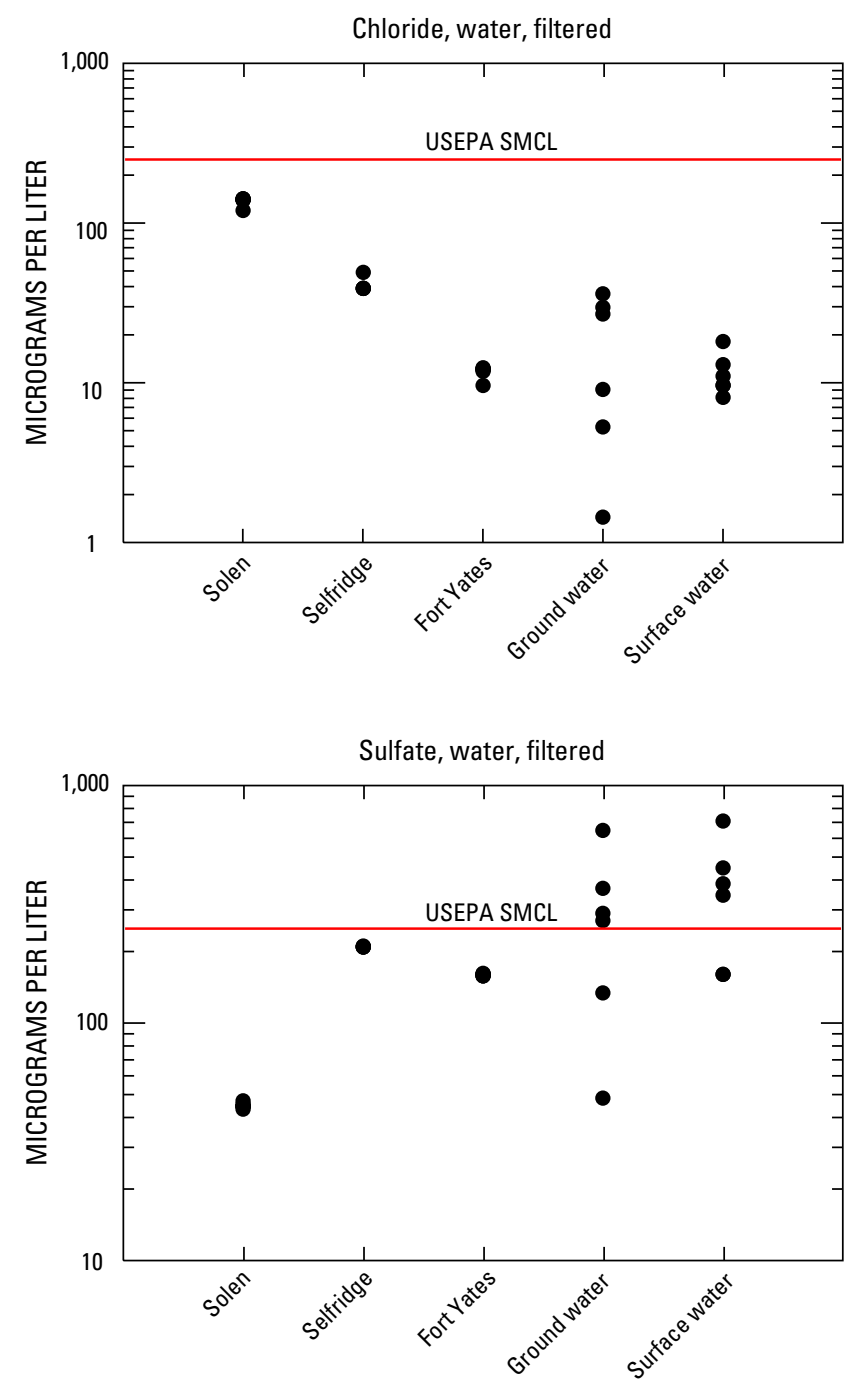

the samples from the target species exceeded the SVs for the selected constituents given the consumption criteria used; however, the gizzard shad, a nontarget species, did exceed the subsistence fishers SV for arsenic. The State of North Dakota administers fish advisories following USEPA guidelines for Lake Oahe and the Missouri River and its major tributaries.

Liver analyses were performed on the northern pike, channel catfish, goldeye, and the common carp. The purposes of these analyses were to evaluate the health of the individual species of fish. These results were not evaluated against any established standards because it was not in the scope of this report.

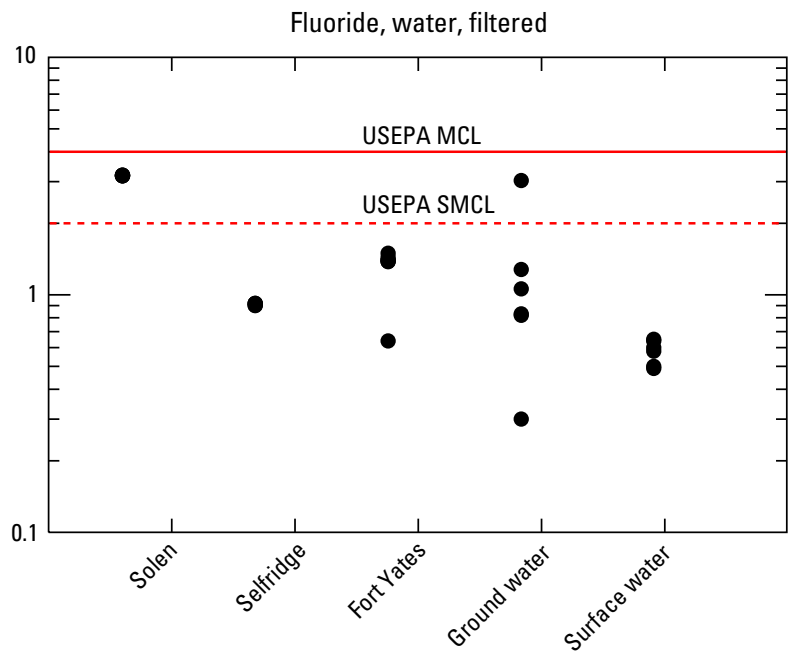

\section{EXPLANATION}

U.S. Environmental Protection Agency Maximum Contaminant Level (USEPA MCL)

U.S. Environmental Protection Agency Secondary Maximum Contaminant Level (USEPA SMCL)

Figure 2. Major inorganic constituents in select public drinking-water sources, ground waters, and surface waters within the Standing Rock Sioux Reservation, North and South Dakota. 
Aluminum, water, filtered

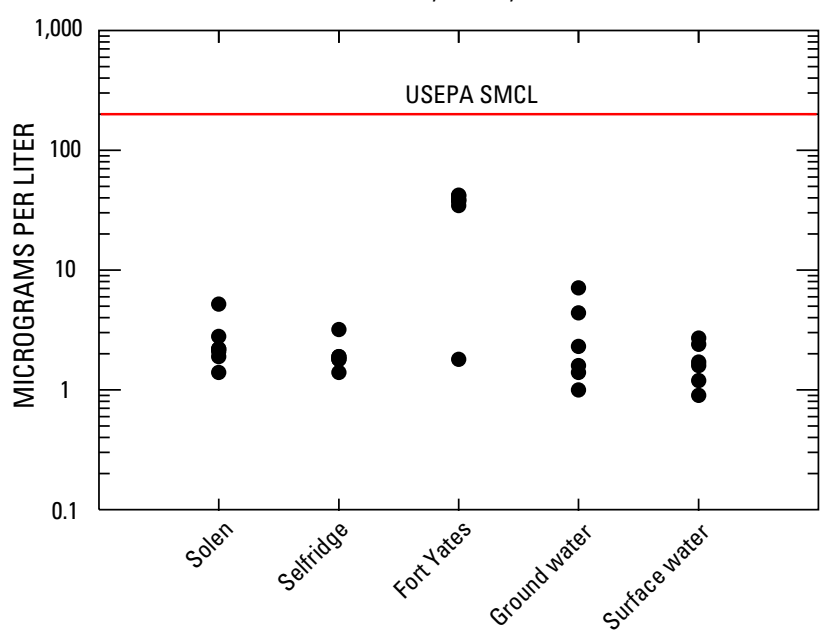

Arsenic, water, filtered

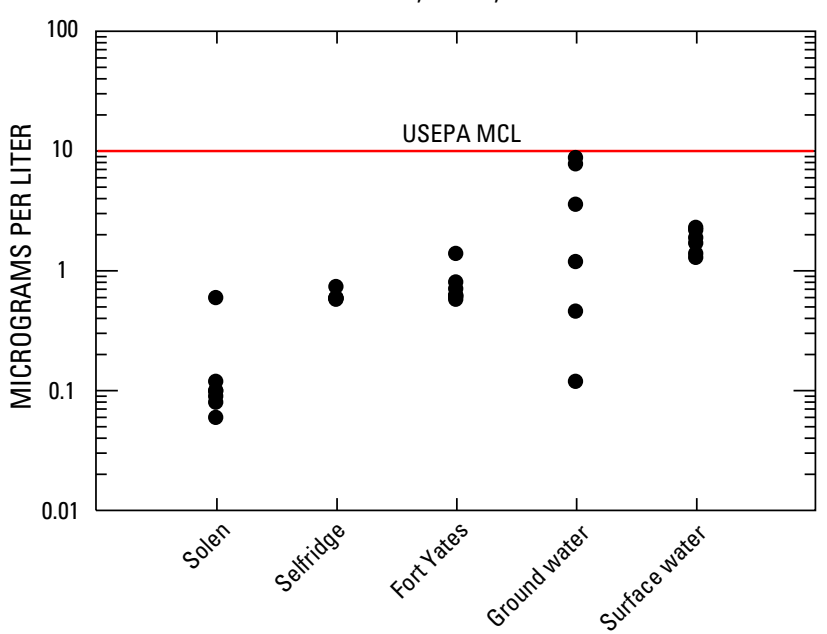

Beryllium, water, filtered

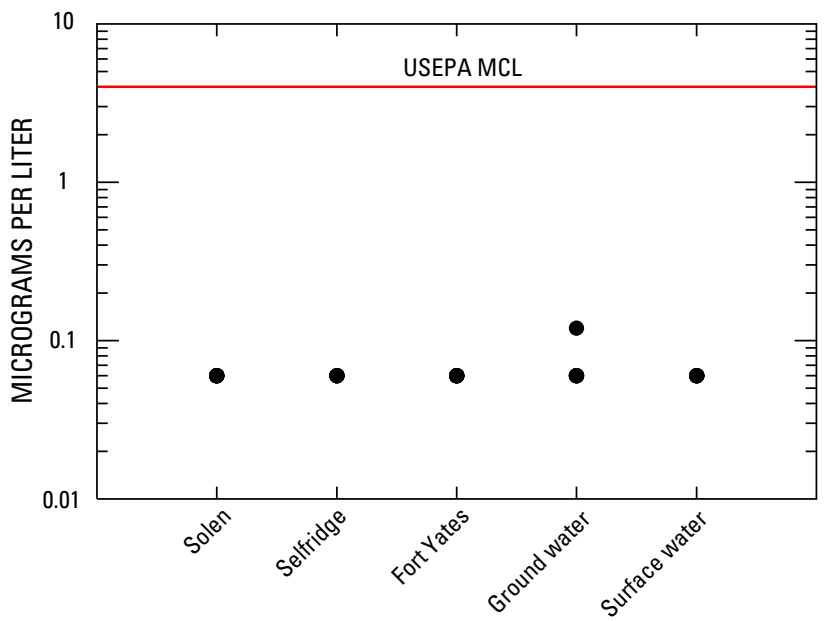

Antimony, water, filtered

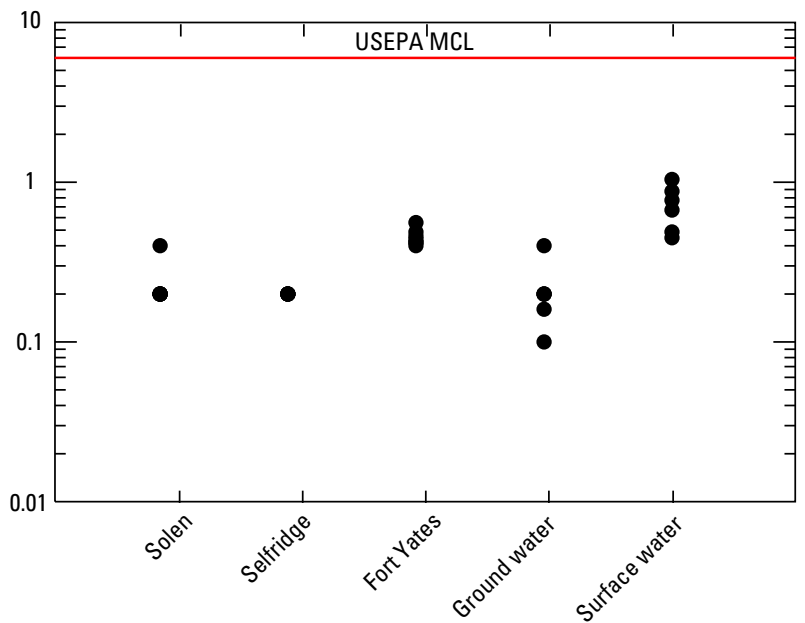

Barium, water, filtered

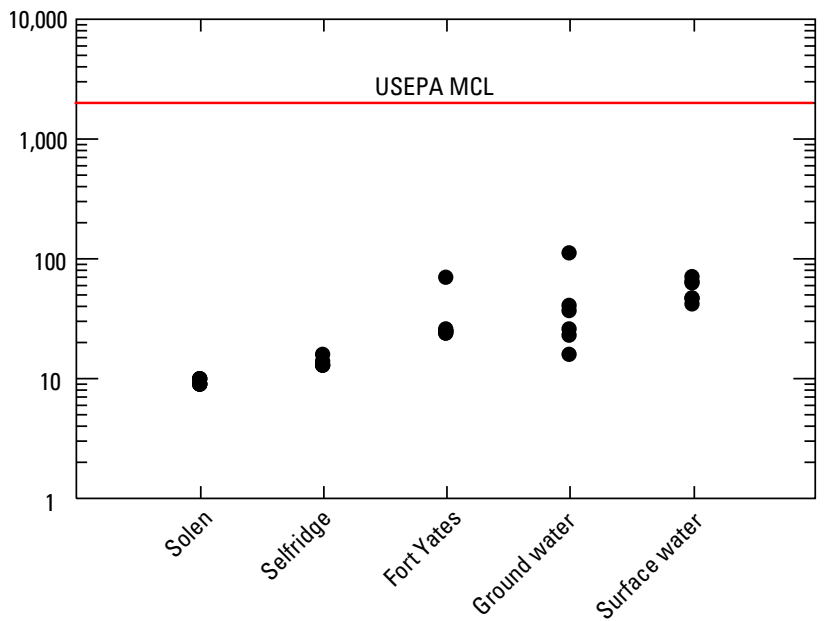

Boron, water, filtered

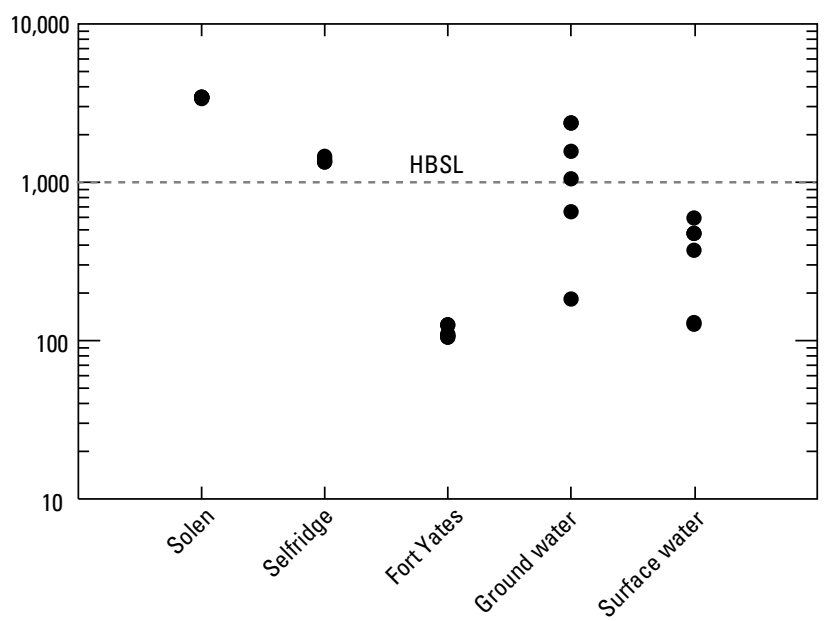

Figure 3. Minor and trace inorganic constituents in select public drinking-water sources, ground waters, and surface waters within the Standing Rock Sioux Reservation, North and South Dakota. 
Nickel, water, filtered

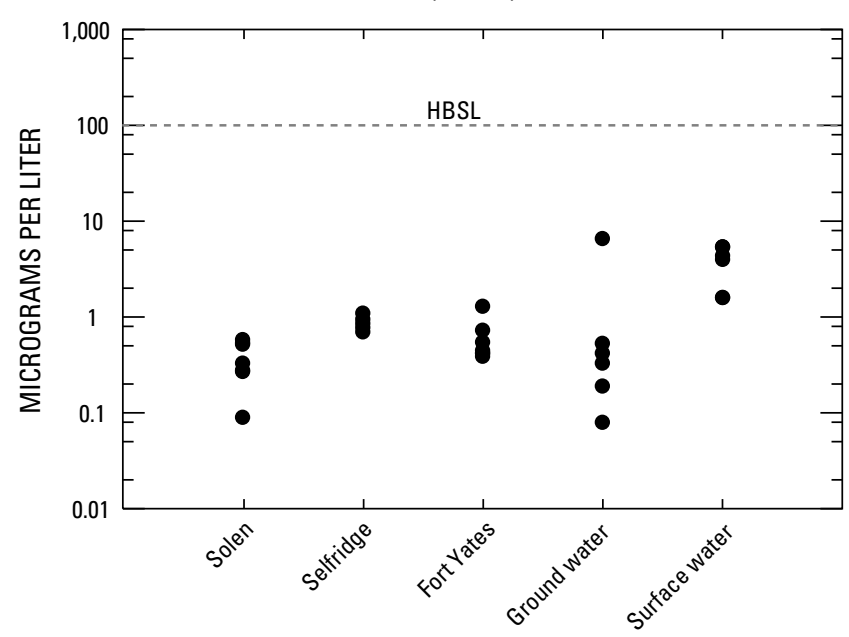

Silver, water, filtered

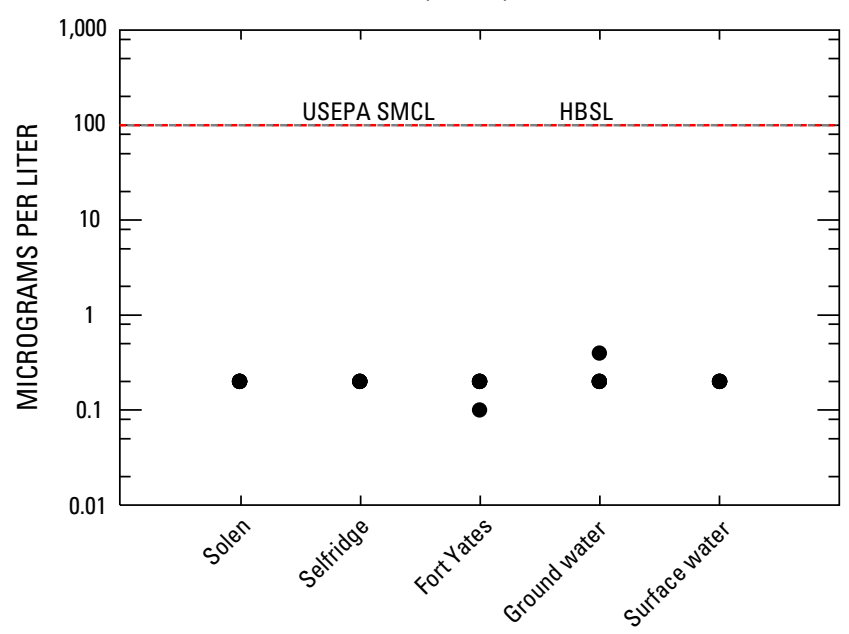

Selenium, water, filtered

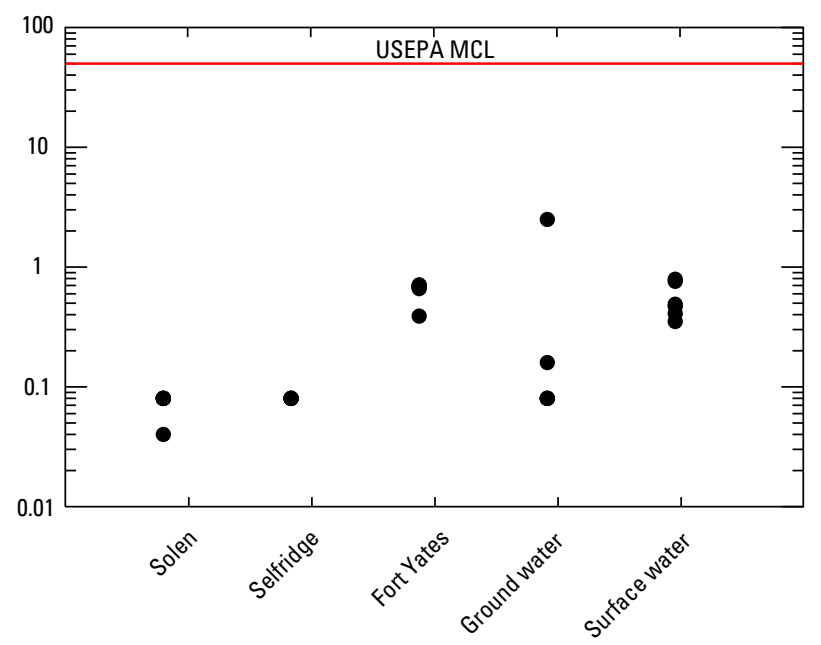

Zinc, water, filtered

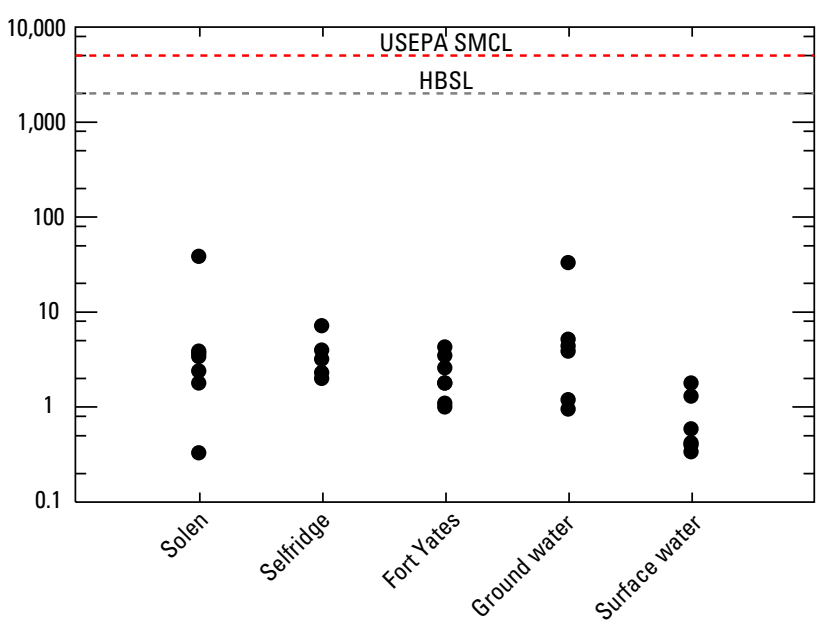

EXPLANATION

U.S. Environmental Protection Agency

Maximum Contaminant Level (USEPA MCL)

U.S. Environmental Protection Agency

Secondary Maximum Contaminant Level

(USEPA SMCL)

Health-Based Screening Level (HBSL)

Figure 3. Minor and trace inorganic constituents in select public drinking-water sources, ground waters, and surface waters within the Standing Rock Sioux Reservation, North and South Dakota.-Continued 
Table 2. Concentrations of minor and trace inorganic constituents in fish tissue and U.S. Environmental Protection Agency Screening Values for target species collected on the Missouri River near Fort Yates, North Dakota.

[Concentrations in micrograms per gram; SV, Screening Value; <, less than]

\begin{tabular}{lccccrr}
\hline \multicolumn{1}{c}{ Sample number } & $\mathbf{3 8}$ & $\mathbf{3 9}$ & $\mathbf{4 1}$ & $\mathbf{4 7}$ & USEPA & USEPA \\
\hline \multicolumn{1}{c}{ Species } & Northern pike & Channel catfish & Common carp & Yellow perch & SV $^{\mathbf{c}}$ & SV $^{\mathbf{2}}$ \\
\hline \multicolumn{1}{c}{ Contaminant } & & & & & & \\
\hline Arsenic & 0.456 & $<0.1$ & $<0.1$ & 0.279 & 26 & 3.27 \\
Cadmium & $<.1$ & $<.1$ & $<.1$ & $<.1$ & 4,000 & 491 \\
Mercury & .241 & .171 & 2.191 & .123 & 400 & 49 \\
Selenium & 2.561 & 2.101 & 3.939 & 3.735 & 20,000 & 2,457 \\
\hline
\end{tabular}

${ }^{1}$ Recreational fishers; based on fish consumption rate of 17.5 grams per day, 70 kilograms body weight.

${ }^{2}$ Subsistence fishers; based on fish consumption rate of 142.4 grams per day, 70 kilograms body weight.

\section{Summary}

Water-quality samples were collected from public watersupply systems, ground water, surface water, bed sediment, and fish tissue within the Standing Rock Sioux Reservation, North and South Dakota, and analyzed to aid in the evaluation of any immediate water-quality concerns. Samples were collected at 32 locations throughout the reservation by U.S. Geological Survey and Standing Rock Sioux Tribe Department of Water Resources personnel from September 11 through 23, 2006.

None of the major inorganic or minor and trace inorganic constituents exceeded the U.S. Environmental Protection Agency (USEPA) Maximum Contaminant Levels (MCLs). Fluoride, manganese, and sulfate concentrations in several samples from the Solen and Selfridge water-delivery systems and from ground water exceeded the USEPA Secondary Maximum Contaminant Levels (SMCLs). Samples collected from the Solen and Selfridge water systems and from ground-water wells had boron concentrations greater than the Health-Based Screening Level (HBSL) of 1,000 micrograms per liter. Boron concentrations in the Solen samples exceeded the HBSL and ranged from $3,380 \mu \mathrm{g} / \mathrm{L}$ to $3,440 \mu \mathrm{g} / \mathrm{L}$.

Of the 29 regulated Volatile Organic Compounds (VOCs) analyzed in samples from the Fort Yates water-delivery system, the four trihalomethanes (THMs) were the most frequently detected in samples collected from water users. The sum of the total THMs (TTHM) for each of the six sites was $64,64,115,85,92$, and 86 micrograms per liter, respectively. The concentrations in samples from four locations exceeded the MCL of 80 micrograms per liter for TTHM. The presence of a free chlorine residual in the water being pumped into the distribution system during the September 2006 sampling period may explain the higher values. Until the free chlorine is removed or reduced to chloride, the THM reaction continues to form THMs, and water users at the end of a distribution may have the largest exposure.
Results from bed-sediment analyses were not compared to any standards, but the State of North Dakota is currently (2007) developing a set of screening standards that can be used in the future.

Minor and trace inorganic constituent concentrations did not exceed USEPA Screening Values in fish tissue of targeted species. The State of North Dakota administers fish advisories following USEPA guidelines for Lake Oahe and the Missouri River and its major tributaries.

\section{References Cited}

Agency for Toxic Substances and Disease Registry (ATSDR), 1992, Toxicological profile for boron: Atlanta, Ga., U.S. Department of Health and Human Services, Public Health Service.

American Public Health Association, 1998, Standard methods for the examination of water and wastewater (20th ed.): Washington, D.C., American Public Health Association, American Water Works Association, and Water Environment Federation, p. 3-37-3-43.

Amundson, F.D., 2002, Estimated use of water in South Dakota, 2000: U.S. Geological Survey Open-File Report 02-440, $17 \mathrm{p}$.

Arbogast, B.F., 1996, Analytical methods for the Mineral Resource Surveys Program: U.S. Geological Survey OpenFile Report 96-525, 248 p.

Briggs, P.H., and Meier, A.L., 1999, The determination of forty two elements in geological materials by inductively coupled plasma-mass spectrometry: U.S. Geological Survey Open-File Report 99-166, 15 p. 
Connor, B.F., Rose, D.L., Noriega, M.C., Murtagh, L.K., and Abney, S.R., 1998, Methods of analysis by the U.S. Geological Survey National Water-Quality Laboratory-determination of 86 volatile organic compounds in water by gas chromatography/mass spectrometry, including detections less than reporting limits: U.S. Geological Survey Open-File Report 97-829, 78 p.

Faires, L.M., 1993, Methods of analysis by the U.S. Geological Survey National Water Quality Laboratory-determination of metals in water by inductively coupled plasma-mass spectrometry: U.S. Geological Survey Open-File Report 92-634, 28 p.

Fishman, M.J., ed., 1993, Methods of analysis by the U.S. Geological Survey National Water Quality Laboratorydetermination of inorganic and organic constituents in water and fluvial sediments: U.S. Geological Survey Open-File Report 93-125, 217 p.

Fishman, M.J., and Friedman, L.C., 1989, Methods for determination of inorganic substances in water and fluvial sediments: U.S. Geological Survey Techniques of WaterResources Investigations, book 5, chap. A1, 545 p.

Garbarino, J.R., 1999, Methods of analysis by the U.S. Geological Survey National Water Quality Laboratory-determination of dissolved arsenic, boron, lithium, selenium, strontium, thallium, and vanadium using inductively coupled plasma-mass spectrometry: U.S. Geological Survey Open-File Report 99-093, 31 p.

Garbarino, J.R., Kanagy, L.K., and Cree, M.E., 2006, Determination of elements in natural-water, biota, sediment, and soil samples using collision/reaction cell inductively coupled plasma-mass spectrometry: U.S. Geological Survey Techniques and Methods, book 5, sec. B, chap.1, 88 p.

Hageman, P.L., 2007, Determination of mercury in aqueous and geologic materials by continuous flow-cold vaporatomic fluorescence spectrometry (CVAFS): U.S. Geological Survey Techniques and Methods, book 5, chap. D2, 6 p.

Hoffman, G.L., 1996, Methods of analysis by the U.S. Geological Survey National Water Quality Laboratorypreparation procedure for aquatic biological material determined for trace metals: U.S. Geological Survey Open-File Report 96-362, 42 p.

Howells, L.W., 1982, Geohydrology of the Standing Rock Indian Reservation, North and South Dakota: U.S. Geological Survey Hydrologic Investigations Atlas HA-644, 5 sheets.
Ivahnenko, T., and Barbash, J.E., 2004, Chloroform in the hydrologic system-sources, transport, fate, occurrence, and effects on human health and aquatic organisms: U.S. Geological Survey Scientific Investigations Report 2004-5137, 34 p.

Ivahnenko, T., and Zogorski, J.S., 2006, Sources and occurrence of chloroform and other trihalomethanes in drinkingwater supply wells in the United States, 1986-2001: U.S. Geological Survey Scientific Investigations Report 2006-5015, 13 p.

Kelly, V.J., Hooper, R.P., Aulenbach, B.T., and Janet, M., 2001, Concentrations and annual fluxes for selected water-quality constituents from the USGS National Stream Quality Accounting Network (NASQAN), 1996-2000: U.S. Geological Survey Water-Resources Investigations Report 01-4255.

Mni Sose Intertribal Rights Coalition, Inc., 2005, Standing Rock Sioux Tribe community environmental profile, accessed June 1, 2005, at http://www.mnisose.org/profiles/ strock.htm

Patton, C.J., and Truitt, E.P., 1992, Methods of analysis by the U.S. Geological Survey National Water Quality Laboratory-determination of total phosphorus by a Kjeldahl digestion method and an automated colorimetric finish that includes dialysis: U.S. Geological Survey Open-File Report 92-146, 39 p.

Patton, C.J., and Truitt, E.P., 2000, Methods of analysis by the U.S. Geological Survey National Water Quality Laboratory - determination of ammonium plus organic nitrogen by a Kjeldahl digestion method and an automated photometric finish that includes digest cleanup by gas diffusion: U.S. Geological Survey Open-File Report 00-170, 31 p.

Struzeski, T.M., DeGiacomo, W.J., and Zayhowski, E.J., 1996, Methods of analysis by the U.S. Geological Survey National Water Quality Laboratory-determination of dissolved aluminum and boron in water by inductively coupled plasmaatomic emission spectrometry: U.S. Geological Survey Open-File Report 96-149, 17 p.

Taggart, J.E., Jr., ed., 2002, Analytical methods for chemical analysis of geologic and other materials, U.S. Geological Survey: U.S. Geological Survey Open-File Report 02-223, $20 \mathrm{p}$.

Toccalino, P.L., Nowell, L.H., Wilber, W.G., Zogorski, J.S., Donohue, J.M., Eiden, C.A., Krietzman, S.J., and Post, G.B., 2003, Development of health-based screening levels for use in state- or local-scale water-quality assessments: U.S. Geological Survey Water-Resources Investigations Report 03-4054, 22 p. 
U.S. Environmental Protection Agency, 1992, Secondary Drinking Water Regulations-guidance for nuisance chemicals, accessed January 17, 2007, at http://www.epa. gov/safewater/consumer/2ndstandards.html

U.S. Environmental Protection Agency, 1994, Summary of EPA finalized National Primary Drinking Water Regulations: U.S. Environmental Protection Agency Region VIII, $7 \mathrm{p}$.

U.S. Environmental Protection Agency, 1996, Microwave assisted acid digestion of siliceous and organically based matrices: U.S. Environmental Protection Agency Method 3052, Revision 0, December 1996, 20 p.

U.S. Environmental Protection Agency, 2000a, Guidance for assessing chemical contaminant data for use in fish advisories: v. 1, Fish sampling and analysis ( $3 \mathrm{~d}$ ed.).

U.S. Environmental Protection Agency, 2000b, Federal Register Document 40 CFR, Part 141: U.S. Environmental Protection Agency, v. 65, no. 104, p. 34404-34405.

U.S. Environmental Protection Agency, 2002, Integrated Risk Information System, accessed March 21, 2007, at http:// www.epa.gov/iris/

U.S. Environmental Protection Agency, 2004, 2004 Edition of the drinking water standards and health advisories: Washington, D.C., Office of Water, U.S. Environmental Protection Agency, EPA 822-R-04-005, 20 p.

U.S. Environmental Protection Agency, 2006a, 2006 Edition of the drinking water standards and health advisories: Washington, D.C., Office of Water, U.S. Environmental Protection Agency, EPA 822-R-04-005, 12 p.

U.S. Environmental Protection Agency, 2006b, Setting standards for safe drinking water, accessed January 17, 2007, at http://www.epa.gov/safewater/standard/setting.html

U.S. Geological Survey, variously dated, National field manual for the collection of water-quality data: U.S. Geological Survey Techniques of Water-Resources Investigations, book 9, chaps. A1-A9, available online at http://pubs.water. usgs.gov/twri9A 
Supplement. Analytical data for water, bed

sediment, and fish tissue within the Standing

Rock Sioux Reservation. 
Table 1-1. Sample location information.

[USDA, U.S. Department of Agriculture; MRI, Municipal, Residential, and Industrial]

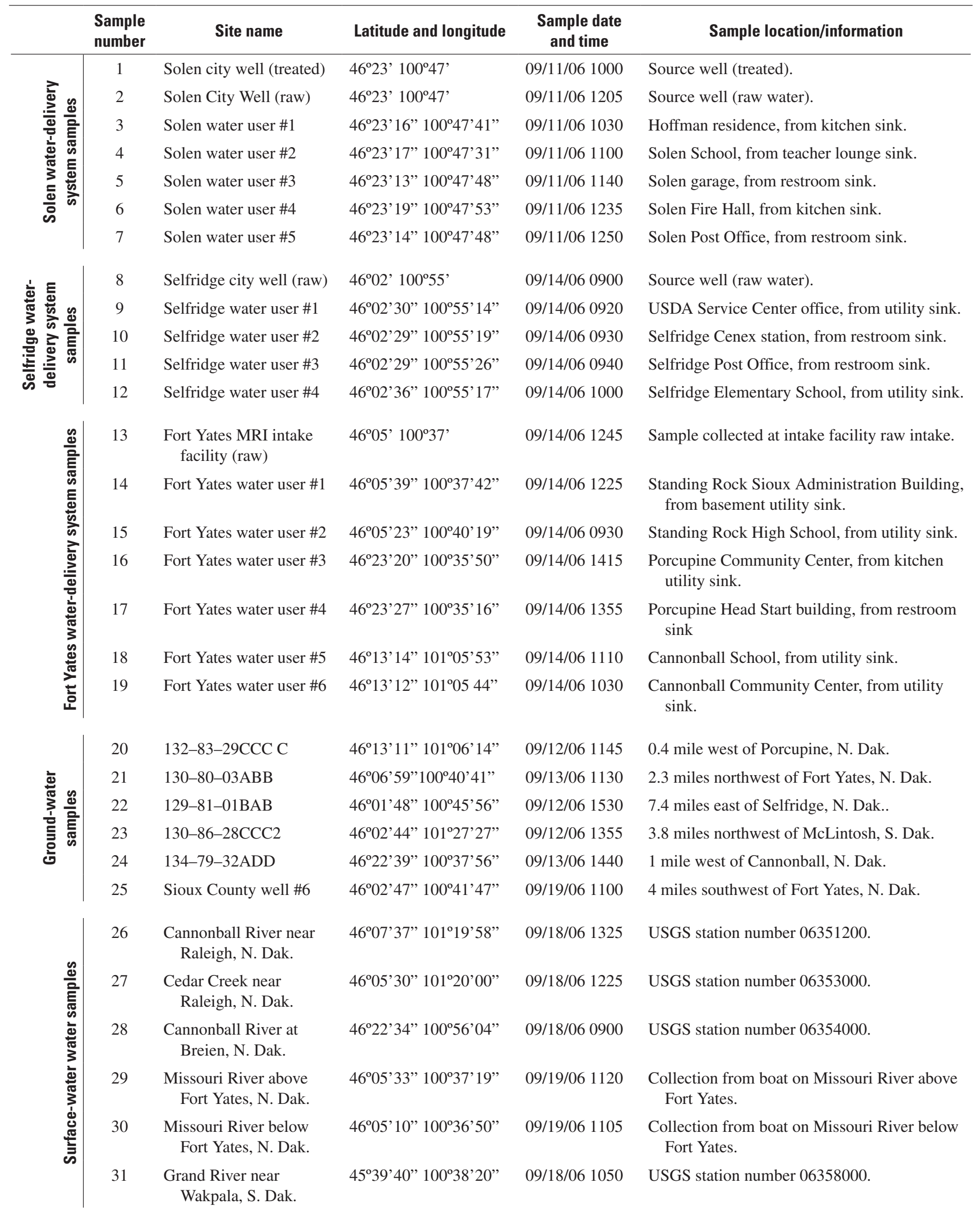


Table 1-1. Sample location information.-Continued

[USDA, U.S. Department of Agriculture; MRI, Municipal, Residential, and Industrial]

\begin{tabular}{|c|c|c|c|c|c|}
\hline & $\begin{array}{l}\text { Sample } \\
\text { number }\end{array}$ & Site name & Latitude and longitude & $\begin{array}{l}\text { Sample date } \\
\text { and time }\end{array}$ & Sample location/information \\
\hline \multirow{6}{*}{ 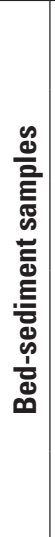 } & 32 & $\begin{array}{l}\text { Cannonball River near } \\
\text { Raleigh, N. Dak. }\end{array}$ & $46^{\circ} 07^{\prime} 37^{\prime \prime} 101^{\circ} 19^{\prime} 58^{\prime \prime}$ & 09/18/06 1325 & Center of river channel. \\
\hline & 33 & $\begin{array}{l}\text { Cedar Creek near } \\
\text { Raleigh, N. Dak. }\end{array}$ & $46^{\circ} 05^{\prime} 30^{\prime \prime} 101^{\circ} 20^{\prime} 00^{\prime \prime}$ & 09/18/06 1225 & Center of river channel. \\
\hline & 34 & $\begin{array}{l}\text { Cannonball River at } \\
\text { Breien, N. Dak. }\end{array}$ & $46^{\circ} 22^{\prime} 34^{\prime \prime} 100^{\circ} 56^{\prime} 04^{\prime \prime}$ & 09/18/06 0900 & Center of river channel. \\
\hline & 35 & $\begin{array}{l}\text { Missouri River above } \\
\text { Fort Yates, N. Dak. }\end{array}$ & $46^{\circ} 05^{\prime} 33^{\prime \prime} 100^{\circ} 37^{\prime} 19^{\prime \prime}$ & 09/19/06 1120 & Center of river channel. \\
\hline & 36 & $\begin{array}{l}\text { Missouri River below } \\
\text { Fort Yates, N. Dak. }\end{array}$ & $46^{\circ} 05^{\prime} 10^{\prime \prime} 100^{\circ} 36^{\prime} 50^{\prime \prime}$ & 09/19/06 1105 & Center of river channel. \\
\hline & 37 & $\begin{array}{l}\text { Grand. River near } \\
\text { Wakpala, S. Dak. }\end{array}$ & $45^{\circ} 39^{\prime} 40^{\prime \prime} 100^{\circ} 38^{\prime} 20^{\prime \prime}$ & 09/18/06 1050 & Center of river channel. \\
\hline \multirow{6}{*}{ 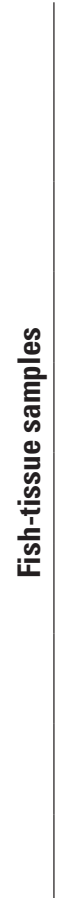 } & 39 & $\begin{array}{c}\text { Missouri River near Fort } \\
\text { Yates, N. Dak. (Fish) }\end{array}$ & $46^{\circ} 05^{\prime} 19^{\prime \prime} 100^{\circ} 36^{\prime} 42^{\prime \prime}$ & 09/23/06 1205 & Tissue sample from channel catfish. \\
\hline & 40 & $\begin{array}{c}\text { Missouri River near Fort } \\
\text { Yates, N. Dak. (Fish) }\end{array}$ & $46^{\circ} 05^{\prime} 19^{\prime \prime} 100^{\circ} 36^{\prime} 42^{\prime \prime}$ & 09/23/06 1210 & Tissue sample from goldeye. \\
\hline & 41 & $\begin{array}{c}\text { Missouri River near Fort } \\
\text { Yates, N. Dak. (Fish) }\end{array}$ & $46^{\circ} 05^{\prime} 19^{\prime \prime} 100^{\circ} 36^{\prime} 42^{\prime \prime}$ & 09/23/06 1215 & Tissue sample from common carp. \\
\hline & 42 & $\begin{array}{c}\text { Missouri River near Fort } \\
\text { Yates, N. Dak. (Fish) }\end{array}$ & $46^{\circ} 05^{\prime} 19^{\prime \prime} 100^{\circ} 36^{\prime} 42^{\prime \prime}$ & 09/23/06 1220 & Tissue sample from common shiner. \\
\hline & 43 & $\begin{array}{c}\text { Missouri River near Fort } \\
\text { Yates, N. Dak. (Fish) }\end{array}$ & $46^{\circ} 05^{\prime} 19^{\prime \prime} 100^{\circ} 36^{\prime} 42^{\prime \prime}$ & $09 / 23 / 061225$ & Tissue sample from green sunfish. \\
\hline & 47 & $\begin{array}{c}\text { Missouri River near Fort } \\
\text { Yates, N. Dak. (Fish) }\end{array}$ & $46^{\circ} 05^{\prime} 19^{\prime \prime} 100^{\circ} 36^{\prime} 42^{\prime \prime}$ & $09 / 23 / 061245$ & Tissue sample from yellow perch. \\
\hline
\end{tabular}


Table 1-2. Analytical results for samples collected from the Solen water-delivery system, Standing Rock Sioux Reservation, North Dakota.

[Sample 1 is raw sample from city supply well; sample 2 is treated sample from supply well; samples 3-7 are from water users. <, less than; E, estimated]

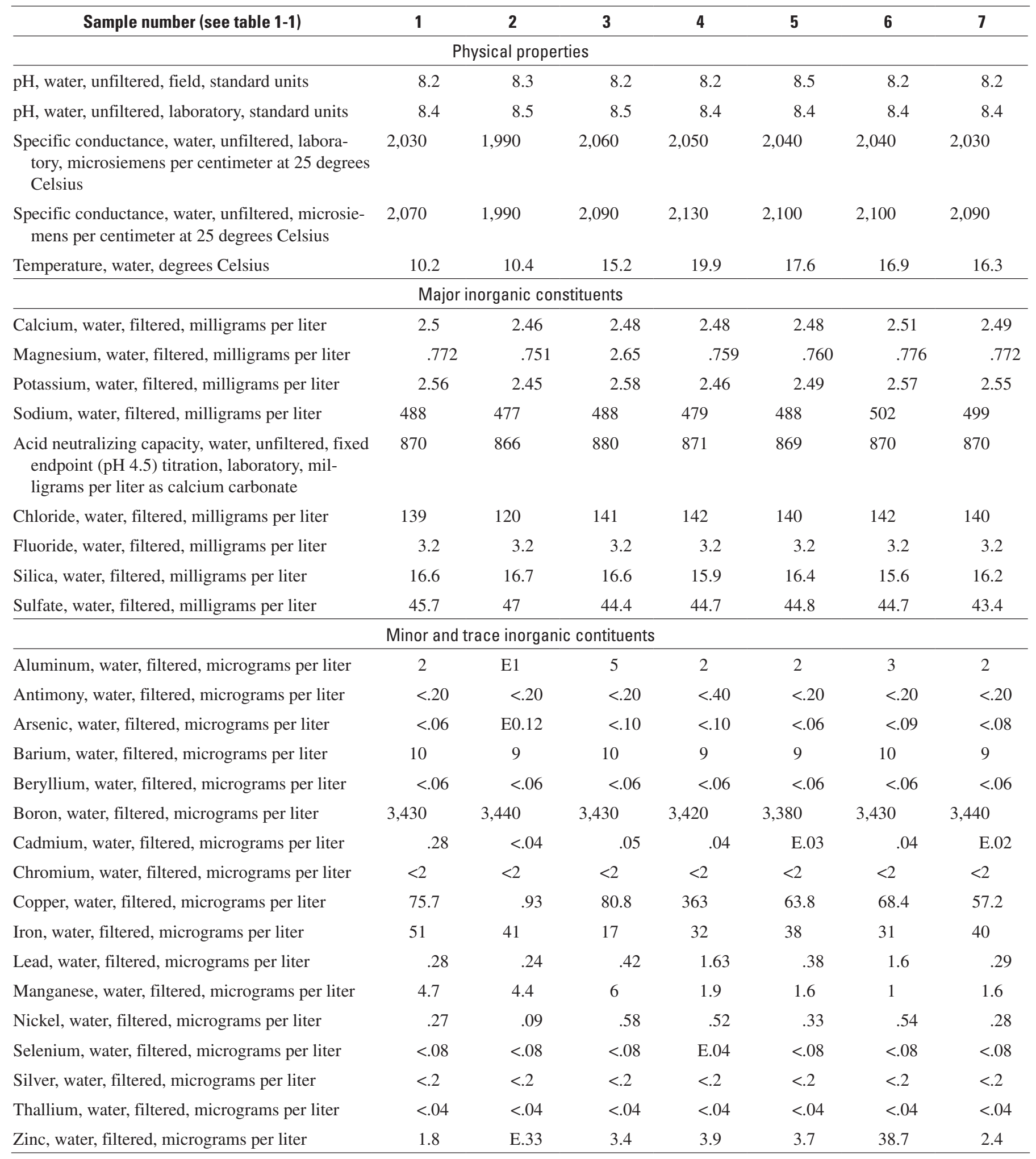


Table 1-3. Analytical results for samples collected from the Selfridge water-delivery system, Standing Rock Sioux Reservation, North Dakota.

[Sample 8 is raw sample from supply well; samples 9-12 are from water users. <, less than; E, estimated]

\begin{tabular}{|c|c|c|c|c|c|}
\hline Sample number (see table 1-1) & 8 & 9 & 10 & 11 & 12 \\
\hline \multicolumn{6}{|c|}{ Physical properties } \\
\hline $\mathrm{pH}$, water, unfiltered, field, standard units & 8.1 & 8.2 & 8.2 & 8.2 & 8.1 \\
\hline $\mathrm{pH}$, water, unfiltered, laboratory, standard units & 8.3 & 8.3 & 8.4 & 8.3 & 8.3 \\
\hline $\begin{array}{l}\text { Specific conductance, water, unfiltered, } \\
\text { laboratory, microsiemens per centimeter } \\
\text { at } 25 \text { degrees Celsius }\end{array}$ & 1,410 & 1,360 & 1,360 & 1,370 & 1,370 \\
\hline $\begin{array}{l}\text { Specific conductance, water, unfiltered, micro- } \\
\text { siemens per centimeter at } 25 \text { degrees Celsius }\end{array}$ & 1,440 & 1,400 & 1,390 & 1,390 & 1,390 \\
\hline Temperature, water, degrees Celsius & 17.1 & 18 & 16.7 & 16.8 & 18.4 \\
\hline \multicolumn{6}{|c|}{ Major inorganic constituents } \\
\hline Calcium, water, filtered, milligrams per liter & 5.49 & 5.36 & 5.38 & 5.37 & 5.25 \\
\hline Magnesium, water, filtered, milligrams per liter & .992 & 1 & 1.02 & .984 & 1.02 \\
\hline Potassium, water, filtered, milligrams per liter & 1.78 & 1.66 & 1.61 & 1.63 & 1.65 \\
\hline Sodium, water, filtered, milligrams per liter & 315 & 306 & 306 & 306 & 300 \\
\hline $\begin{array}{l}\text { Acid neutralizing capacity, water, unfiltered, } \\
\text { fixed endpoint ( } \mathrm{pH} 4.5 \text { ) titration, laboratory, } \\
\text { milligrams per liter as calcium carbonate }\end{array}$ & 445 & 440 & 440 & 440 & 440 \\
\hline Chloride, water, filtered, milligrams per liter & 49.1 & 39 & 39 & 39 & 39 \\
\hline Fluoride, water, filtered, milligrams per liter & .9 & .9 & .9 & .9 & .9 \\
\hline Silica, water, filtered, milligrams per liter & 17.8 & 16.6 & 16.8 & 16.6 & 16.6 \\
\hline Sulfate, water, filtered, milligrams per liter & 209 & 211 & 210 & 209 & 210 \\
\hline \multicolumn{6}{|c|}{ Minor and trace inorganic constituents } \\
\hline Aluminum, water, filtered, micrograms per liter & 2 & 2 & E1 & 2 & 3 \\
\hline Antimony, water, filtered, micrograms per liter & $<.20$ & $<.20$ & $<.20$ & $<.20$ & $<.20$ \\
\hline Arsenic, water, filtered, micrograms per liter & .74 & .58 & .59 & .59 & .6 \\
\hline Barium, water, filtered, micrograms per liter & 16 & 13 & 13 & 14 & 13 \\
\hline Beryllium, water, filtered, micrograms per liter & $<.06$ & $<.06$ & $<.06$ & $<.06$ & $<.06$ \\
\hline Boron, water, filtered, micrograms per liter & 1,460 & 1,370 & 1,340 & 1,410 & 1,350 \\
\hline Cadmium, water, filtered, micrograms per liter & $<.04$ & $<.04$ & $<.04$ & $<.04$ & $<.04$ \\
\hline Chromium, water, filtered, micrograms per liter & $<6$ & $<2$ & $<2$ & $<6$ & $<6$ \\
\hline Copper, water, filtered, micrograms per liter & 1.3 & 160 & 25.2 & 56 & 41.6 \\
\hline Iron, water, filtered, micrograms per liter & 108 & 57 & 61 & 55 & 60 \\
\hline Lead, water, filtered, micrograms per liter & .29 & .23 & .22 & .20 & .26 \\
\hline Manganese, water, filtered, micrograms per liter & 13.1 & 8.7 & 9 & 8.2 & 9.4 \\
\hline Nickel, water, filtered, micrograms per liter & .70 & 1.1 & .86 & .78 & .95 \\
\hline Selenium, water, filtered, micrograms per liter & $<.08$ & $<.08$ & $<.08$ & $<.08$ & $<.08$ \\
\hline Silver, water, filtered, micrograms per liter & $<.2$ & $<.2$ & $<.2$ & $<.2$ & $<.2$ \\
\hline Thallium, water, filtered, micrograms per liter & $<.04$ & $<.04$ & $<.04$ & $<.04$ & $<.04$ \\
\hline Zinc, water, filtered, micrograms per liter & 7.2 & 2.3 & 4 & 2 & 3.2 \\
\hline
\end{tabular}


Table 1-4. Analytical results for samples collected from the Fort Yates water-delivery system, Standing Rock Sioux Reservation, North Dakota.

[Sample 13 is raw sample from water intake; samples 14-19 are from water users. <, less than; E, estimated; THM, trihalomethane]

\begin{tabular}{|c|c|c|c|c|c|c|c|}
\hline Sample number (see table 1-1) & 13 & 14 & 15 & 16 & 17 & 18 & 19 \\
\hline \multicolumn{8}{|c|}{ Physical properties } \\
\hline $\mathrm{pH}$, water, unfiltered, field, standard units & 8.2 & 9.2 & 9 & 9.1 & 9.2 & 9.2 & 9.2 \\
\hline $\begin{array}{l}\text { Specific conductance, water, unfiltered, } \\
\text { laboratory, microsiemens per centimeter } \\
\text { at } 25 \text { degrees Celsius }\end{array}$ & 659 & 528 & 532 & 523 & 528 & 530 & 523 \\
\hline Temperature, water, degrees Celsius & 20 & 21.2 & 15.6 & 21.6 & 18.6 & 19.7 & 20.6 \\
\hline \multicolumn{8}{|c|}{ Major inorganic constituents } \\
\hline Calcium, water, filtered, milligrams per liter & 48.8 & 33.6 & 32.4 & 31.4 & 34.1 & 33.3 & 32.5 \\
\hline $\begin{array}{l}\text { Acid neutralizing capacity, water, unfiltered, } \\
\text { fixed endpoint ( } \mathrm{pH} 4.5 \text { ) titration, laboratory, } \\
\text { milligrams per liter, as calcium carbonate }\end{array}$ & 165 & 65 & 66 & 63 & 65 & 65 & 64 \\
\hline Chloride, water, filtered, milligrams per liter & 9.6 & 12.2 & 12.1 & 12.4 & 12.2 & 11.8 & 12.1 \\
\hline Fluoride, water, filtered, milligrams per liter & .60 & 1.4 & 1.5 & 1.4 & 1.4 & 1.4 & 1.4 \\
\hline Silica, water, filtered, milligrams per liter & 5.84 & 6.09 & 6.17 & 5.97 & 5.89 & 6.07 & 6 \\
\hline Sulfate, water, filtered, milligrams per liter & 158 & 160 & 161 & 161 & 158 & 158 & 162 \\
\hline $\begin{array}{l}\text { Organic carbon, water, filtered, milligrams per } \\
\text { liter }\end{array}$ & 3.2 & 2.7 & 2.5 & 2.4 & 2.9 & 2.7 & 3 \\
\hline $\begin{array}{l}\text { Ammonia, water, filtered, milligrams per liter } \\
\text { as nitrogen }\end{array}$ & .013 & E.008 & $<.010$ & $<.010$ & $<.010$ & $<.010$ & $<.010$ \\
\hline $\begin{array}{l}\text { Nitrite plus nitrate, water, filtered, milligrams } \\
\text { per liter, as nitrogen }\end{array}$ & .10 & .11 & .11 & .11 & .11 & .13 & .12 \\
\hline $\begin{array}{l}\text { Nitrite, water, filtered, milligrams per liter, as } \\
\text { nitrogen }\end{array}$ & E.001 & $<.002$ & $<.002$ & $<.002$ & $<.002$ & $<.002$ & $<.002$ \\
\hline $\begin{array}{l}\text { Orthophosphate, water, filtered, milligrams per } \\
\text { liter, as phosphorus }\end{array}$ & .006 & .137 & .134 & .163 & .138 & .159 & .137 \\
\hline Phosphorus, water, filtered, milligrams per liter & $<.04$ & .34 & .29 & .32 & .32 & .31 & .34 \\
\hline $\begin{array}{l}\text { Phosphorus, water, unfiltered, milligrams per } \\
\text { liter }\end{array}$ & .04 & .34 & .30 & .31 & .32 & .32 & .33 \\
\hline
\end{tabular}
liter 
Table 1-4. Analytical results for samples collected from the Fort Yates water-delivery system, Standing Rock Sioux Reservation, North Dakota.-Continued

[Sample 13 is raw sample from water intake; samples 14-19 are from water users. <, less than; E, estimated; THM, trihalomethane]

\begin{tabular}{|c|c|c|c|c|c|c|c|}
\hline Sample number (see table 1-1) & 13 & 14 & 15 & 16 & 17 & 18 & 19 \\
\hline \multicolumn{8}{|c|}{ Minor and trace inorganic constituents } \\
\hline Aluminum, water, filtered, micrograms per liter & 2 & 39 & 35 & 42 & 38 & 42 & 39 \\
\hline Arsenic, water, filtered, micrograms per liter & 1.4 & .58 & .81 & .61 & .62 & .71 & 63 \\
\hline Barium, water, filtered, micrograms per liter & 70 & 24 & 24 & 25 & 26 & 25 & 25 \\
\hline Boron, water, filtered, micrograms per liter & 125 & 110 & 126 & 105 & 108 & 108 & 105 \\
\hline Cadmium, water, filtered, micrograms per liter & $<.04$ & $<.04$ & $<.04$ & $<.04$ & E.02 & $<.04$ & $<.04$ \\
\hline Chromium, water, filtered, micrograms per liter & $<2$ & E1 & $<2$ & $<2$ & E1 & E1 & $<2$ \\
\hline Copper, water, filtered, micrograms per liter & 13 & 5.9 & 4.6 & 7.7 & 3.4 & .85 & 5.1 \\
\hline Nickel, water, filtered, micrograms per liter & 1.3 & .55 & .73 & .39 & .42 & .42 & .45 \\
\hline Selenium, water, filtered, micrograms per liter & .71 & .68 & .39 & .69 & .69 & .70 & .66 \\
\hline Silver, water, filtered, micrograms per liter & $<.2$ & $<.2$ & E.1 & $<.2$ & $<.2$ & $<.2$ & $<.2$ \\
\hline Thallium, water, filtered, micrograms per liter & $<.04$ & $<.04$ & $<.04$ & $<.04$ & $<.04$ & $<.04$ & $<.04$ \\
\hline Zinc, water, filtered, micrograms per liter & 1.8 & 1.8 & 4.3 & 1.1 & 3.5 & 1 & 2.6 \\
\hline \multicolumn{8}{|c|}{ Volatile inorganic compounds } \\
\hline $\begin{array}{l}\text { 1,1,1-Trichloroethane, water, unfiltered, recov- } \\
\text { erable, micrograms per liter }\end{array}$ & $<0.1$ & $<0.1$ & $<0.1$ & $<0.1$ & $<0.1$ & $<0.1$ & $<0.1$ \\
\hline $\begin{array}{l}\text { 1,1,2-Trichloro-1,2,2-trifluoroethane, water, } \\
\text { unfiltered, recoverable, micrograms per liter }\end{array}$ & $<.1$ & $<.1$ & $<.1$ & $<.1$ & $<.1$ & $<.1$ & $<.1$ \\
\hline $\begin{array}{l}\text { 1,2-Dichloroethane, water, unfiltered, recover- } \\
\text { able, micrograms per liter }\end{array}$ & $<.2$ & $<.2$ & $<.2$ & $<.2$ & $<.2$ & $<.2$ & $<.2$ \\
\hline $\begin{array}{l}\text { 1,2-Dichloroethane-d4, surrogate, Schedule } \\
\text { 2090, water, unfiltered, percent recovery }\end{array}$ & 111 & 109 & 114 & 111 & 111 & 109 & 111 \\
\hline $\begin{array}{l}\text { 1,2-Dichloropropane, water, unfiltered, recover- } \\
\text { able, micrograms per liter }\end{array}$ & $<.1$ & $<.1$ & $<.1$ & $<.1$ & $<.1$ & $<.1$ & $<.1$ \\
\hline $\begin{array}{l}\text { 1,3-Dichlorobenzene, water, unfiltered, recover- } \\
\text { able, micrograms per liter }\end{array}$ & $<.1$ & $<.1$ & $<.1$ & $<.1$ & $<.1$ & $<.1$ & $<.1$ \\
\hline $\begin{array}{l}\text { 1,4-Dichlorobenzene, water, unfiltered, recover- } \\
\text { able, micrograms per liter }\end{array}$ & $<.1$ & $<.1$ & $<.1$ & $<.1$ & $<.1$ & $<.1$ & $<.1$ \\
\hline $\begin{array}{l}\text { 1-Bromo-4-fluorobenzene, surrogate, VOC } \\
\text { schedules, water, unfiltered, percent recovery }\end{array}$ & 96.5 & 97.4 & 99.8 & 97.5 & 97.6 & 99.1 & 98.3 \\
\hline $\begin{array}{l}\text { Benzene, water, unfiltered, recoverable, micro- } \\
\text { grams per liter }\end{array}$ & $<.1$ & $<.1$ & $<.1$ & $<.1$ & $<.1$ & $<.1$ & $<.1$ \\
\hline
\end{tabular}


Table 1-4. Analytical results for samples collected from the Fort Yates water-delivery system, Standing Rock Sioux Reservation, North Dakota.-Continued

[Sample 13 is raw sample from water intake; samples 14-19 are from water users. <, less than; E, estimated; THM, trihalomethane]

\begin{tabular}{|c|c|c|c|c|c|c|c|}
\hline Sample number (see table 1-1) & 13 & 14 & 15 & 16 & 17 & 18 & 19 \\
\hline \multicolumn{8}{|c|}{ Volatile inorganic compounds-Continued } \\
\hline $\begin{array}{l}\text { (THM) Bromodichloromethane, water, unfil- } \\
\text { tered, recoverable, micrograms per liter }\end{array}$ & $<0.1$ & 16.2 & 16.8 & 20.5 & 19 & 18 & 19.2 \\
\hline $\begin{array}{l}\text { Chlorobenzene, water, unfiltered, recoverable, } \\
\text { micrograms per liter }\end{array}$ & $<.1$ & $<.1$ & $<.1$ & $<.1$ & $<.1$ & $<.1$ & $<.1$ \\
\hline $\begin{array}{l}\text { cis-1,2-Dichloroethene, water, unfiltered, recov- } \\
\text { erable, micrograms per liter }\end{array}$ & $<.1$ & $<.1$ & $<.1$ & $<.1$ & $<.1$ & $<.1$ & $<.1$ \\
\hline $\begin{array}{l}\text { (THM) Dibromochloromethane, water, unfil- } \\
\text { tered, recoverable, micrograms per liter }\end{array}$ & $<.2$ & 6.6 & 6.8 & 7.9 & 7.5 & 7.7 & 7.6 \\
\hline $\begin{array}{l}\text { Dichlorodifluoromethane, water, unfiltered, } \\
\text { recoverable, micrograms per liter }\end{array}$ & $<.2$ & $<.2$ & $<.2$ & $<.2$ & $<.2$ & $<.2$ & $<.2$ \\
\hline $\begin{array}{l}\text { Dichloromethane, water, unfiltered, recoverable, } \\
\text { micrograms per liter }\end{array}$ & $<.2$ & $<.2$ & $<.2$ & $<.2$ & $<.2$ & $<.2$ & $<.2$ \\
\hline $\begin{array}{l}\text { Diethyl ether, water, unfiltered, recoverable, } \\
\text { micrograms per liter }\end{array}$ & $<.2$ & $<.2$ & $<.2$ & $<.2$ & $<.2$ & $<.2$ & $<.2$ \\
\hline $\begin{array}{l}\text { Diisopropyl ether, water, unfiltered, recoverable, } \\
\text { micrograms per liter }\end{array}$ & $<.2$ & $<.2$ & $<.2$ & $<.2$ & $<.2$ & $<.2$ & $<.2$ \\
\hline $\begin{array}{l}\text { Ethylbenzene, water, unfiltered, recoverable, } \\
\text { micrograms per liter }\end{array}$ & $<.1$ & $<.1$ & $<.1$ & $<.1$ & $<.1$ & $<.1$ & $<.1$ \\
\hline $\begin{array}{l}\text { Methyl tert-pentyl ether, water, unfiltered, } \\
\text { recoverable, micrograms per liter }\end{array}$ & $<.2$ & $<.2$ & $<.2$ & $<.2$ & $<.2$ & $<.2$ & $<.2$ \\
\hline $\begin{array}{l}m \text {-Xylene plus } p \text {-xylene, water, unfiltered, } \\
\text { recoverable, micrograms per liter }\end{array}$ & $<.2$ & $<.2$ & $<.2$ & E. 2 & $<.2$ & E.1 & E.1 \\
\hline $\begin{array}{l}o \text {-Xylene, water, unfiltered, recoverable, micro- } \\
\text { grams per liter }\end{array}$ & $<.1$ & $<.1$ & $<.1$ & $<.1$ & $<.1$ & $<.1$ & $<.1$ \\
\hline $\begin{array}{l}\text { Styrene, water, unfiltered, recoverable, micro- } \\
\text { grams per liter }\end{array}$ & $<.1$ & $<.1$ & $<.1$ & $<.1$ & $<.1$ & $<.1$ & $<.1$ \\
\hline $\begin{array}{l}\text { tert-Butyl ethyl ether, water, unfiltered, recover- } \\
\text { able, micrograms per liter }\end{array}$ & $<.1$ & $<.1$ & $<.1$ & $<.1$ & $<.1$ & $<.1$ & $<.1$ \\
\hline $\begin{array}{l}\text { Methyl tert-butyl ether, water, unfiltered, recov- } \\
\text { erable, micrograms per liter }\end{array}$ & $<.2$ & $<.2$ & $<.2$ & $<.2$ & $<.2$ & $<.2$ & $<.2$ \\
\hline $\begin{array}{l}\text { Tetrachloroethene, water, unfiltered, recover- } \\
\text { able, micrograms per liter }\end{array}$ & $<.1$ & $<.1$ & $<.1$ & $<.1$ & $<.1$ & $<.1$ & $<.1$ \\
\hline $\begin{array}{l}\text { Tetrachloromethane, water, unfiltered, recover- } \\
\text { able, micrograms per liter }\end{array}$ & $<.2$ & $<.2$ & $<.2$ & 0.2 & $<.2$ & 0.3 & 0.3 \\
\hline $\begin{array}{l}\text { Toluene, water, unfiltered, recoverable, micro- } \\
\text { grams per liter }\end{array}$ & $<.1$ & $<.1$ & $<.1$ & $<.1$ & $<.1$ & $<.1$ & $<.1$ \\
\hline $\begin{array}{l}\text { Toluene-d8, surrogate, Schedule 2090, water, } \\
\text { unfiltered, percent recovery }\end{array}$ & 101 & 101 & 102 & 101 & 101 & 101 & 100 \\
\hline $\begin{array}{l}\text { trans-1,2-Dichloroethene, water, unfiltered, } \\
\text { recoverable, micrograms per liter }\end{array}$ & $<.1$ & $<.1$ & $<.1$ & $<.1$ & $<.1$ & $<.1$ & $<.1$ \\
\hline $\begin{array}{l}\text { (THM) Tribromomethane, water, unfiltered, } \\
\text { recoverable, micrograms per liter }\end{array}$ & $<.2$ & 6 & 6 & .8 & .7 & .7 & .7 \\
\hline $\begin{array}{l}\text { Trichloroethene, water, unfiltered, recoverable, } \\
\text { micrograms per liter }\end{array}$ & $<.1$ & $<.1$ & $<.1$ & $<.1$ & $<.1$ & $<.1$ & $<.1$ \\
\hline
\end{tabular}


Table 1-4. Analytical results for samples collected from the Fort Yates water-delivery system, Standing Rock Sioux Reservation, North Dakota.-Continued

[Sample 13 is raw sample from water intake; samples 14-19 are from water users. <, less than; E, estimated; THM, trihalomethane]

\begin{tabular}{|c|c|c|c|c|c|c|c|}
\hline Sample number (see table 1-1) & 13 & 14 & 15 & 16 & 17 & 18 & 19 \\
\hline \multicolumn{8}{|c|}{ Volatile inorganic compounds-Continued } \\
\hline $\begin{array}{l}\text { Trichlorofluoromethane, water, unfiltered, } \\
\text { recoverable, micrograms per liter }\end{array}$ & $<0.2$ & $<0.2$ & $<0.2$ & $<0.2$ & $<0.2$ & $<0.2$ & $<0.2$ \\
\hline $\begin{array}{l}\text { (THM) Trichloromethane, water, unfiltered, } \\
\text { recoverable, micrograms per liter }\end{array}$ & $<.1$ & 40.6 & 40.2 & 86 & 58.1 & 65.8 & 58.7 \\
\hline
\end{tabular}


Table 1-5. Analytical results for samples collected from select ground-water sources, Standing Rock Sioux Reservation, North Dakota. $[<$, less than; E, estimated; M, verified but not quantified]

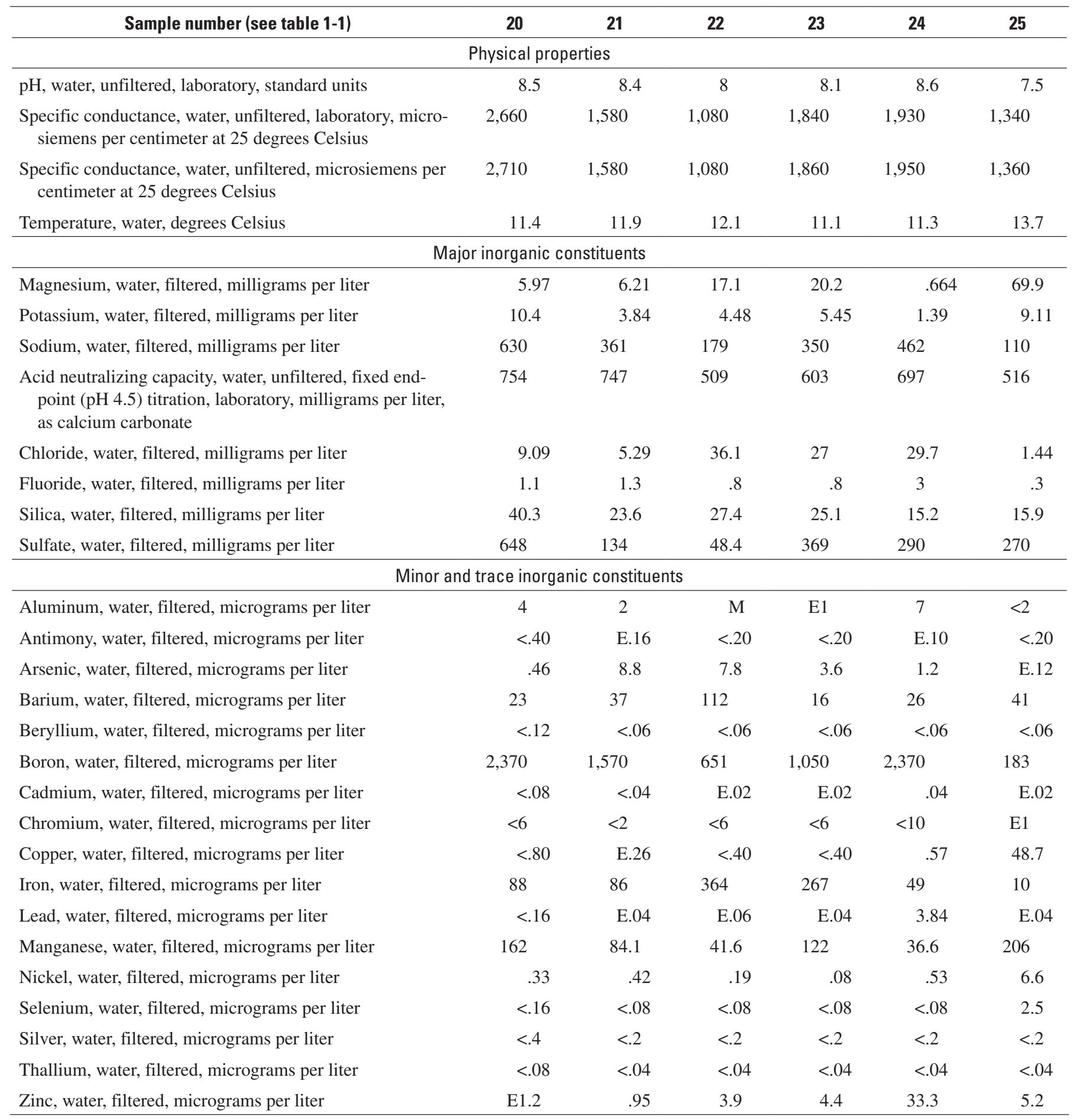


Table 1-6. Analytical results for samples collected from select surface-water and bed-sediment sources, Standing Rock Sioux Reservation, North and South Dakota.

[Second sample number is bed-sediment sample. <, less than; E, estimated; M, verified but not quantified]

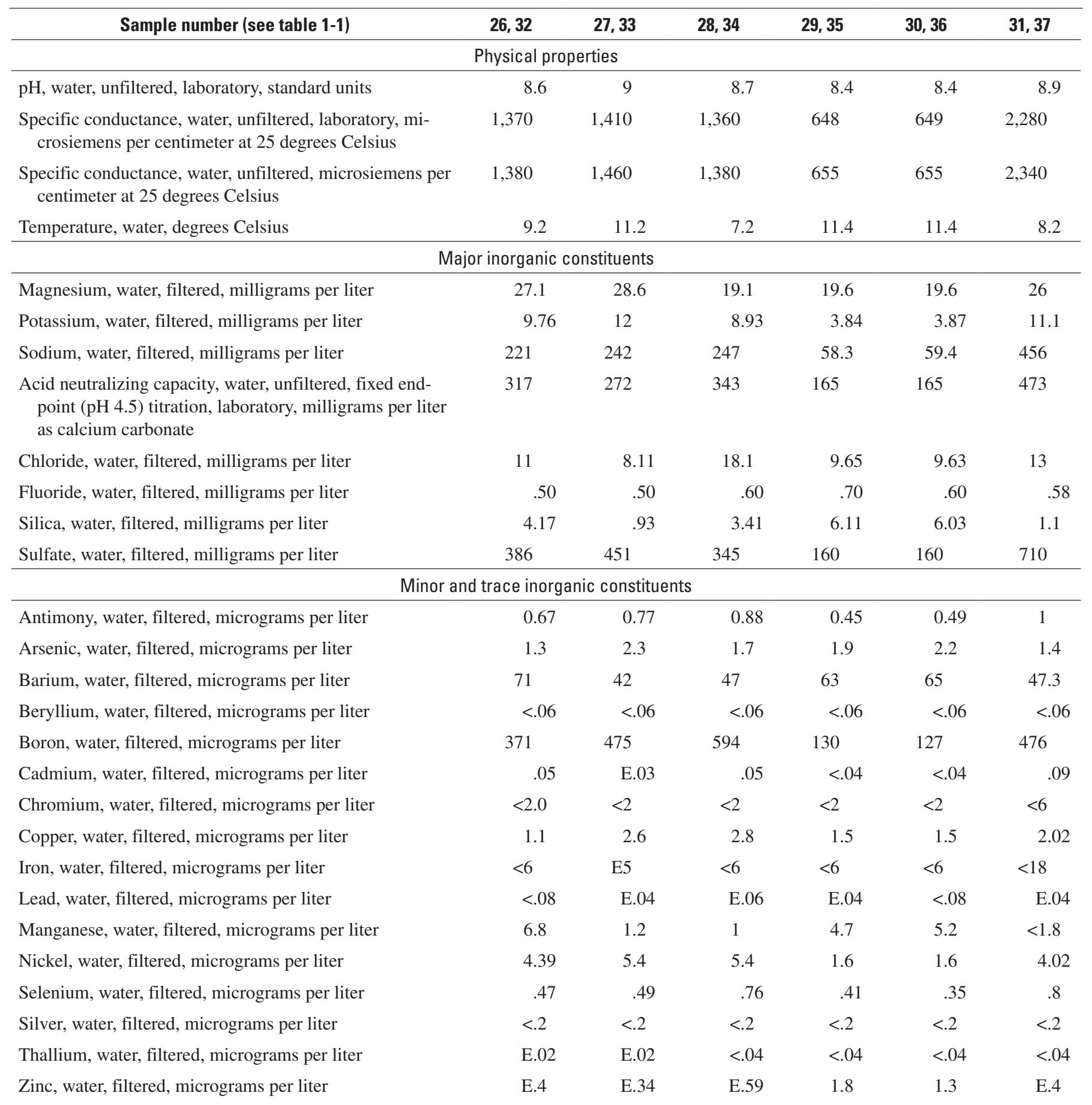


Table 1-6. Analytical results for samples collected from select surface-water and bed-sediment sources, Standing Rock Sioux Reservation, North and South Dakota.-Continued

[Second sample number is bed-sediment sample. <, less than; E, estimated; M, verified but not quantified]

\begin{tabular}{|c|c|c|c|c|c|c|}
\hline Sample number (see table 1-1) & 26,32 & 27,33 & 28,34 & 29,35 & 30,36 & 31,37 \\
\hline \multicolumn{7}{|c|}{ Major, minor, and trace inorganic constituents in bed sediment } \\
\hline $\begin{array}{l}\text { Antimony, bed sediment smaller than } 62.5 \text { microns, wet } \\
\text { sieved, field, total digestion, dry weight, micrograms } \\
\text { per gram }\end{array}$ & 6.9 & 1.1 & 3.3 & 0.5 & 0.4 & 1 \\
\hline $\begin{array}{l}\text { Arsenic, bed sediment smaller than } 62.5 \text { microns, wet } \\
\text { sieved, field, total digestion, dry weight, micrograms } \\
\text { per gram }\end{array}$ & 120 & 4.6 & 59 & 7.3 & 6.1 & 7.6 \\
\hline $\begin{array}{l}\text { Barium, bed sediment smaller than } 62.5 \text { microns, wet } \\
\text { sieved, field, total digestion, dry weight, micrograms } \\
\text { per gram }\end{array}$ & 810 & 450 & 820 & 940 & 840 & 683 \\
\hline $\begin{array}{l}\text { Beryllium, bed sediment smaller than } 62.5 \text { microns, wet } \\
\text { sieved, field, total digestion, dry weight, micrograms } \\
\text { per gram }\end{array}$ & 2.1 & 2.1 & 1.5 & 1.2 & 1 & 2.3 \\
\hline $\begin{array}{l}\text { Cadmium, bed sediment smaller than } 62.5 \text { microns, wet } \\
\text { sieved, field, total digestion, dry weight, micrograms } \\
\text { per gram }\end{array}$ & .70 & .40 & .30 & .10 & .10 & .38 \\
\hline $\begin{array}{l}\text { Calcium, bed sediment smaller than } 62.5 \text { microns, wet } \\
\text { sieved, field, total digestion, dry weight, micrograms } \\
\text { per gram }\end{array}$ & 8,400 & 12,000 & 7,400 & 26,000 & 23,000 & 10,600 \\
\hline $\begin{array}{l}\text { Inorganic carbon, bed sediment smaller than } 62.5 \mathrm{mi}- \\
\text { crons, wet sieved (native water), field, recoverable, dry } \\
\text { weight, percent }\end{array}$ & 6 & 1.3 & .5 & 1.3 & .8 & 1.1 \\
\hline $\begin{array}{l}\text { Cesium, bed sediment smaller than } 62.5 \text { microns, wet } \\
\text { sieved, field, total digestion, dry weight, micrograms } \\
\text { per gram }\end{array}$ & 1.2 & 4.8 & 1.7 & 2.2 & 1.4 & 5.9 \\
\hline $\begin{array}{l}\text { Chromium, bed sediment smaller than } 62.5 \text { microns, wet } \\
\text { sieved, field, total digestion, dry weight, micrograms } \\
\text { per gram }\end{array}$ & 24 & 62 & 30 & 50 & 42 & 113 \\
\hline $\begin{array}{l}\text { Cobalt, bed sediment smaller than } 62.5 \text { microns, wet } \\
\text { sieved, field, total digestion, dry weight, micrograms } \\
\text { per gram }\end{array}$ & 32 & 8 & 18 & 7 & 6 & 15.2 \\
\hline $\begin{array}{l}\text { Copper, bed sediment smaller than } 62.5 \text { microns, wet } \\
\text { sieved, field, total digestion, dry weight, micrograms } \\
\text { per gram }\end{array}$ & 22 & 22 & 14 & 12 & 5 & 36 \\
\hline
\end{tabular}


Table 1-6. Analytical results for samples collected from select surface-water and bed-sediment sources, Standing Rock Sioux Reservation, North and South Dakota.-Continued

[Second sample number is bed-sediment sample. <, less than; E, estimated; M, verified but not quantified]

\begin{tabular}{|c|c|c|c|c|c|c|}
\hline Sample number (see table 1-1) & 26,32 & 27,33 & 28,34 & 29,35 & 30,36 & 31,37 \\
\hline \multicolumn{7}{|c|}{ Major, minor, and trace inorganic constituents in bed sediment-Continued } \\
\hline $\begin{array}{l}\text { Gallium, bed sediment smaller than } 62.5 \text { microns, wet } \\
\text { sieved, field, total digestion, dry weight, micrograms } \\
\text { per gram }\end{array}$ & 5 & 17 & 8 & 9 & 8 & 21 \\
\hline $\begin{array}{l}\text { Iron, bed sediment smaller than } 62.5 \text { microns, wet sieved, } \\
\text { field, total digestion, dry weight, micrograms per gram }\end{array}$ & 230,000 & 29,000 & 100,000 & 17,000 & 14,000 & 43,900 \\
\hline $\begin{array}{l}\text { Lead, bed sediment smaller than } 62.5 \text { microns, wet } \\
\text { sieved, field, total digestion, dry weight, micrograms } \\
\text { per gram }\end{array}$ & 23 & 21 & 17 & 11 & 10 & 19 \\
\hline $\begin{array}{l}\text { Magnesium, bed sediment smaller than } 62.5 \text { microns, wet } \\
\text { sieved, field, total digestion, dry weight, micrograms } \\
\text { per gram }\end{array}$ & 2,700 & 14,000 & 4,800 & 12,000 & 9,700 & 13,200 \\
\hline $\begin{array}{l}\text { Manganese, bed sediment smaller than } 62.5 \text { microns, wet } \\
\text { sieved, field, total digestion, dry weight, micrograms } \\
\text { per gram }\end{array}$ & 4,200 & 320 & 1,800 & 280 & 230 & 630 \\
\hline $\begin{array}{l}\text { Mercury, bed sediment smaller than } 62.5 \text { microns, wet } \\
\text { sieved, field, total digestion, dry weight, micrograms } \\
\text { per gram }\end{array}$ & .03 & .04 & .03 & .04 & $<.02$ & .10 \\
\hline $\begin{array}{l}\text { Molybdenum, bed sediment smaller than } 62.5 \text { microns, } \\
\text { wet sieved, field, total digestion, dry weight, micro- } \\
\text { grams per gram }\end{array}$ & 18 & 1.5 & 6.8 & .5 & .4 & 1.3 \\
\hline $\begin{array}{l}\text { Phosphorus, bed sediment smaller than } 62.5 \text { microns, wet } \\
\text { sieved, field, total digestion, dry weight, micrograms } \\
\text { per gram }\end{array}$ & 1,100 & 490 & 710 & 700 & 540 & 550 \\
\hline $\begin{array}{l}\text { Potassium, bed sediment smaller than } 62.5 \text { microns, wet } \\
\text { sieved, field, total digestion, dry weight, micrograms } \\
\text { per gram }\end{array}$ & 8,300 & 16,000 & 14,000 & 16,000 & 15,000 & 16,000 \\
\hline $\begin{array}{l}\text { Rubidium, bed sediment smaller than } 62.5 \text { microns, wet } \\
\text { sieved, field, total digestion, dry weight, micrograms } \\
\text { per gram }\end{array}$ & 29.2 & 70.8 & 45 & 55.2 & 45.5 & 78.8 \\
\hline $\begin{array}{l}\text { Scandium, bed sediment smaller than } 62.5 \text { microns, wet } \\
\text { sieved, field, total digestion, dry weight, micrograms } \\
\text { per gram }\end{array}$ & 8 & 11 & 6 & 6 & 5 & 18 \\
\hline $\begin{array}{l}\text { Selenium, bed sediment smaller than } 62.5 \text { microns, wet } \\
\text { sieved, field, total digestion, dry weight, micrograms } \\
\text { per gram }\end{array}$ & 3.8 & .34 & 1.4 & .16 & .08 & .79 \\
\hline
\end{tabular}


Table 1-6. Analytical results for samples collected from select surface-water and bed-sediment sources, Standing Rock Sioux Reservation, North and South Dakota.-Continued

[Second sample number is bed-sediment sample. <, less than; E, estimated; M, verified but not quantified]

\begin{tabular}{|c|c|c|c|c|c|c|}
\hline Sample number (see table 1-1) & 26,32 & 27,33 & 28,34 & 29,35 & 30,36 & 31,37 \\
\hline \multicolumn{7}{|c|}{ Major, minor, and trace inorganic constituents in bed sediment-Continued } \\
\hline $\begin{array}{l}\text { Silver, bed sediment smaller than } 62.5 \text { microns, wet } \\
\text { sieved, field, total digestion, dry weight, micrograms } \\
\text { per gram }\end{array}$ & $<1.0$ & $<1.0$ & $<1.0$ & $<1.0$ & $<1.0$ & $<1.0$ \\
\hline $\begin{array}{l}\text { Sodium, bed sediment smaller than } 62.5 \text { microns, wet } \\
\text { sieved, field, total digestion, dry weight, micrograms } \\
\text { per gram }\end{array}$ & 3,400 & 8,700 & 7,800 & 11,000 & 11,000 & 6,900 \\
\hline $\begin{array}{l}\text { Strontium, bed sediment smaller than } 62.5 \text { microns, wet } \\
\text { sieved, field, total digestion, dry weight, micrograms } \\
\text { per gram }\end{array}$ & 120 & 170 & 170 & 210 & 210 & 190 \\
\hline $\begin{array}{l}\text { Sulfur, bed sediment smaller than } 62.5 \text { microns, wet } \\
\text { sieved, field, total digestion, dry weight, percent }\end{array}$ & .06 & .05 & .09 & $<.05$ & $<.05$ & .10 \\
\hline $\begin{array}{l}\text { Thorium, bed sediment smaller than } 62.5 \text { microns, wet } \\
\text { sieved, field, total digestion, dry weight, micrograms } \\
\text { per gram }\end{array}$ & 4 & 13 & 4 & 9 & 6 & 11 \\
\hline $\begin{array}{l}\text { Titanium, bed sediment smaller than } 62.5 \text { microns, wet } \\
\text { sieved, field, total digestion, dry weight, micrograms } \\
\text { per gram }\end{array}$ & 660 & 2,900 & 1,100 & 2,400 & 1,800 & 4,500 \\
\hline $\begin{array}{l}\text { Uranium, bed sediment smaller than } 62.5 \text { microns, wet } \\
\text { sieved, field, total digestion, dry weight, micrograms } \\
\text { per gram }\end{array}$ & 4.3 & 4 & 2.4 & 1.9 & 1.4 & 2.9 \\
\hline $\begin{array}{l}\text { Vanadium, bed sediment smaller than } 62.5 \text { microns, wet } \\
\text { sieved, field, total digestion, dry weight, micrograms } \\
\text { per gram }\end{array}$ & 100 & 85 & 81 & 56 & 42 & 178 \\
\hline
\end{tabular}




\begin{tabular}{|c|c|c|c|c|c|c|c|c|c|c|c|c|c|c|c|c|}
\hline f & 을 흘 & & $\overrightarrow{\dot{v}}$ & $\stackrel{\overbrace{}}{ヘ}$ & $\stackrel{n}{n}$ & $\overrightarrow{\mathrm{v}}$ & $\vec{i}$ & $\overrightarrow{\mathrm{v}}$ & $\infty$. & ฯ & $\stackrel{9}{-}$ & iิ & $\Upsilon$ & $\hat{\vec{j}}$ & $\stackrel{\overbrace{}}{\simeq}$ & $\overrightarrow{\mathrm{v}}$ \\
\hline \& & 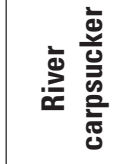 & & $\overrightarrow{\dot{v}}$ & 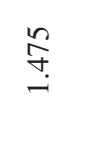 & nn & $\overrightarrow{\mathrm{v}}$ & $\vec{i}$ & $\overrightarrow{\mathrm{v}}$ & N & 0 & $\stackrel{m}{m}$ & $\stackrel{\infty}{\infty}$ & $n$ & $\stackrel{\vec{v}}{\vec{v}}$ & 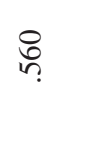 & - \\
\hline 8 & 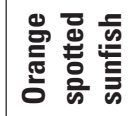 & & $\overrightarrow{\vec{v}}$ & $\stackrel{\searrow}{\ni}$ & $\begin{array}{l}0 \\
\stackrel{\infty}{-}\end{array}$ & $\overrightarrow{\mathrm{v}}$ & $\stackrel{\Upsilon}{-}$ & $\overrightarrow{\mathrm{v}}$ & $\infty$. & ণ & $\exists$ & $\underset{\infty}{+\infty}$ & - & $\underset{m}{m}$ & तิ & $\Upsilon$ \\
\hline g & 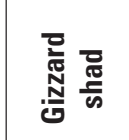 & & $\overrightarrow{\dot{v}}$ & 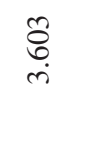 & $\stackrel{\Upsilon}{\underset{f}{f}}$ & 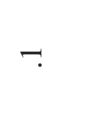 & $\dot{m}$ & 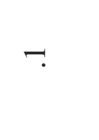 & $n$ & $\dddot{n}$ & $\stackrel{\circ}{r}$ & $\begin{array}{l}\text { : } \\
\text { n్ }\end{array}$ & $\stackrel{0}{-}$ & तె' & $\tilde{a}$ & ণ \\
\hline ஜ & 离 & & $\overrightarrow{\dot{v}}$ & 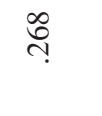 & $\stackrel{\circ}{=}$ & $\overrightarrow{\mathrm{v}}$ & $\exists$ & $\overrightarrow{\mathrm{v}}$ & $\infty$. & ฯ & $r$ & 辇 & ฯ & 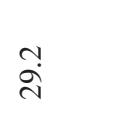 & $\overrightarrow{0}$ & - \\
\hline ₹ & 旁 & & $\overrightarrow{\dot{v}}$ & $\stackrel{0}{ }$ & $\stackrel{\check{2}}{2}$ & $\overrightarrow{\mathrm{v}}$ & $\stackrel{?}{-}$ & $\overrightarrow{\mathrm{v}}$ & - & ণ & $\stackrel{9}{-}$ & ठે & ฯ & $\stackrel{\bullet}{\vec{\lambda}}$ & $\exists$ & ฯ \\
\hline$\mp$ & 흘 응 & 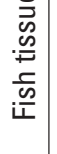 & $\overrightarrow{\dot{v}}$ & $\overrightarrow{\mathrm{v}}$ & $n$ & $\overrightarrow{\mathrm{v}}$ & $r$ & $\overrightarrow{\mathrm{v}}$ & $\stackrel{n}{v}$ & $\overrightarrow{\mathrm{v}}$ & $\stackrel{n}{\longrightarrow}$ & 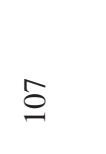 & $\overrightarrow{\mathrm{v}}$ & 0 & $\stackrel{\vec{i}}{i}$ & $\overrightarrow{\mathrm{v}}$ \\
\hline q & $\frac{0}{\frac{\partial}{0}}$ & & $\overrightarrow{\dot{v}}$ & $\cong$ & $\exists$ & $\overrightarrow{\mathrm{v}}$ & $\forall$ & $\overrightarrow{\mathrm{v}}$ & 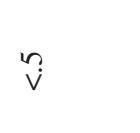 & $\vec{v}$ & o. & mై & $\overrightarrow{\mathrm{v}}$ & ฯ & $\underset{\infty}{+}$ & $\vec{v}$ \\
\hline శ్ల & 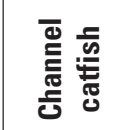 & & $\overrightarrow{\dot{v}}$ & $\overrightarrow{\mathrm{v}}$ & $\overrightarrow{\mathrm{v}}$ & $\overrightarrow{\mathrm{v}}$ & $n$ & $\overrightarrow{\mathrm{v}}$ & 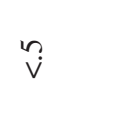 & $\overrightarrow{\mathrm{v}}$ & 0 & $\stackrel{9}{=}$ & $\overrightarrow{\mathrm{v}}$ & ナ. & $\Xi$ & $\overrightarrow{\mathrm{v}}$ \\
\hline ? & 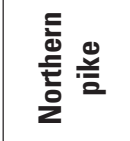 & & $\overrightarrow{\dot{v}}$ & iั & 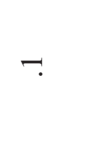 & $\overrightarrow{\mathrm{v}}$ & $n$ & $\vec{v}$ & $\stackrel{n}{v}$ & $\overrightarrow{\mathrm{v}}$ & 9 & $\stackrel{m}{m}$ & $\overrightarrow{\mathrm{v}}$ & $\exists$ & $\stackrel{+}{\sim}$ & $\overrightarrow{\mathrm{v}}$ \\
\hline 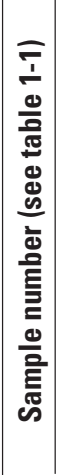 & 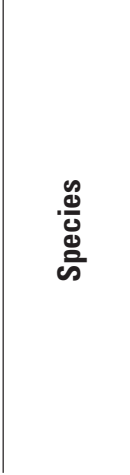 & & 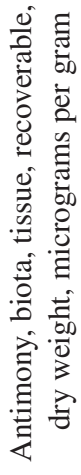 & 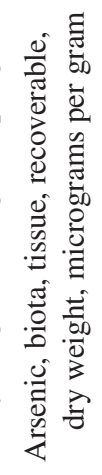 & 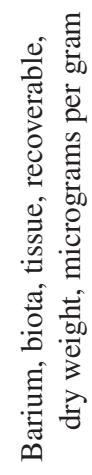 & 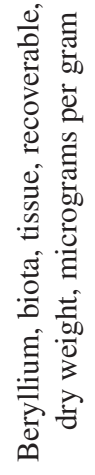 & 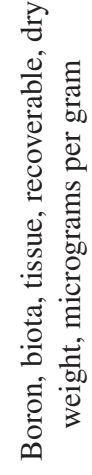 & 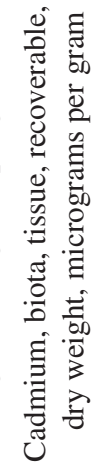 & 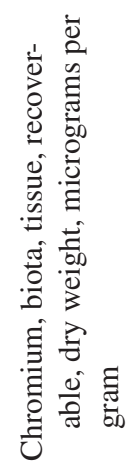 & 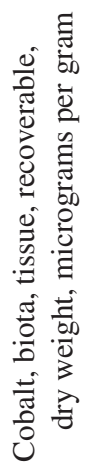 & 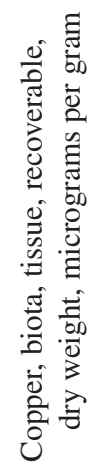 & 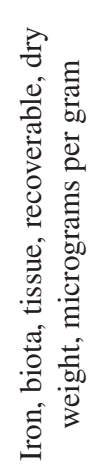 & 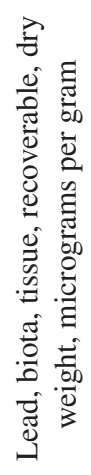 & 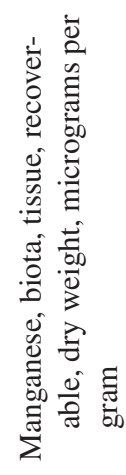 & 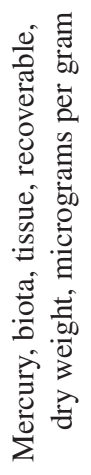 & 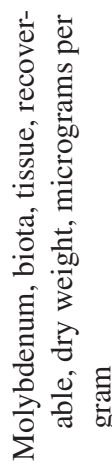 \\
\hline
\end{tabular}




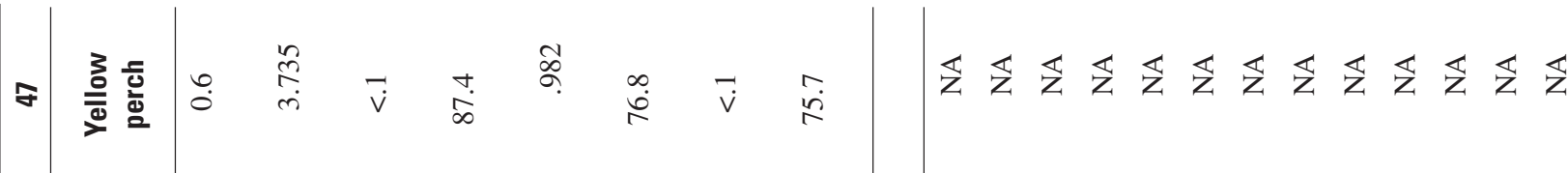

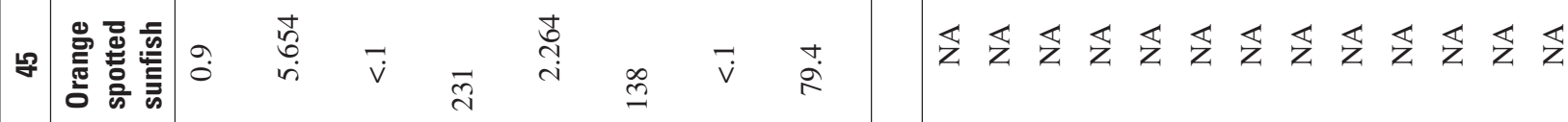

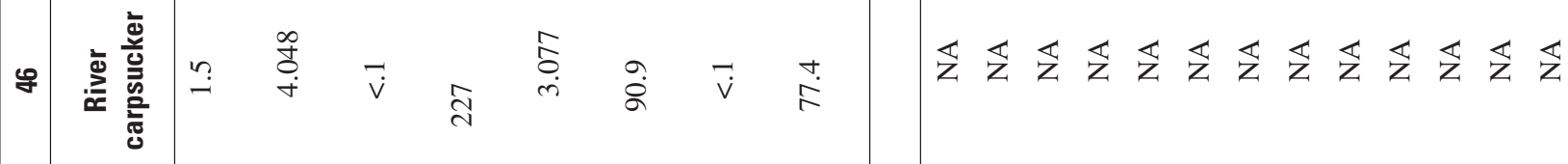

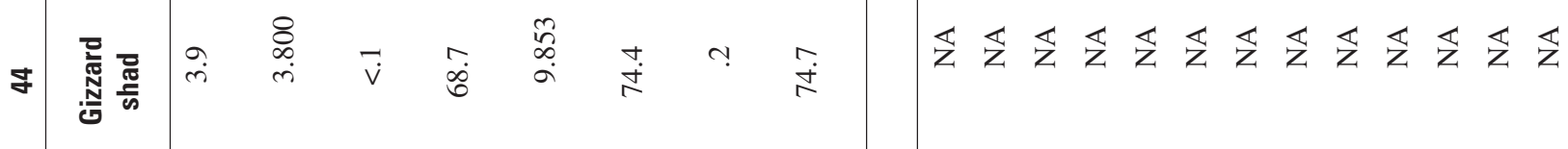

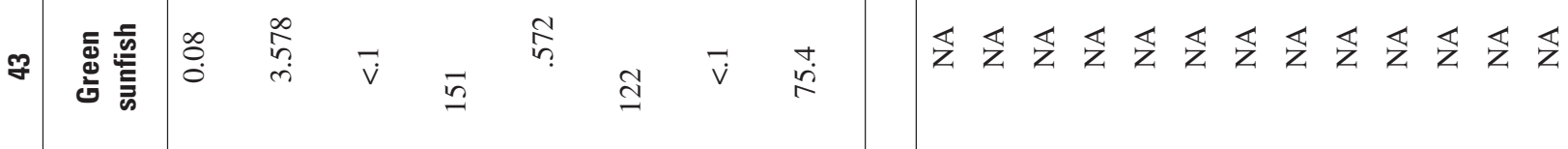

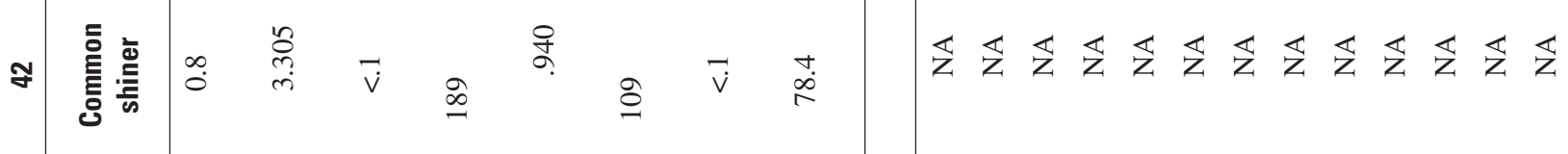

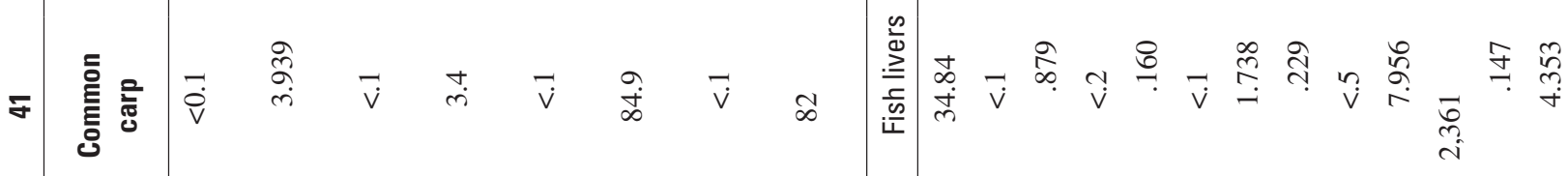

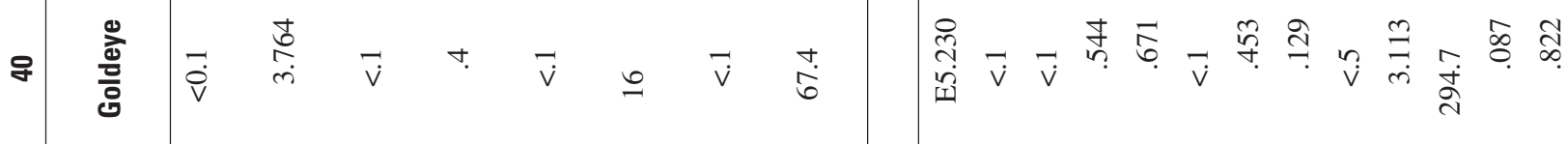

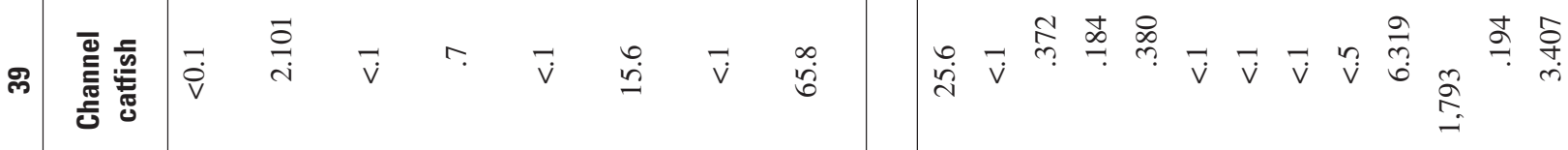

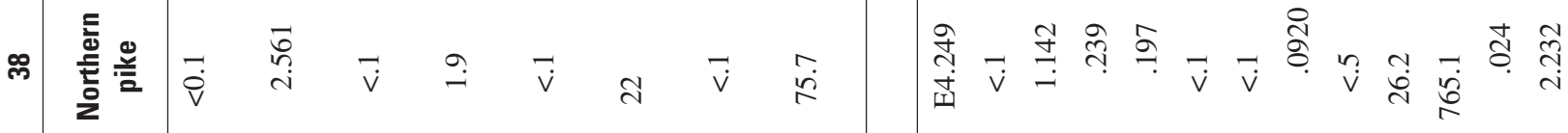

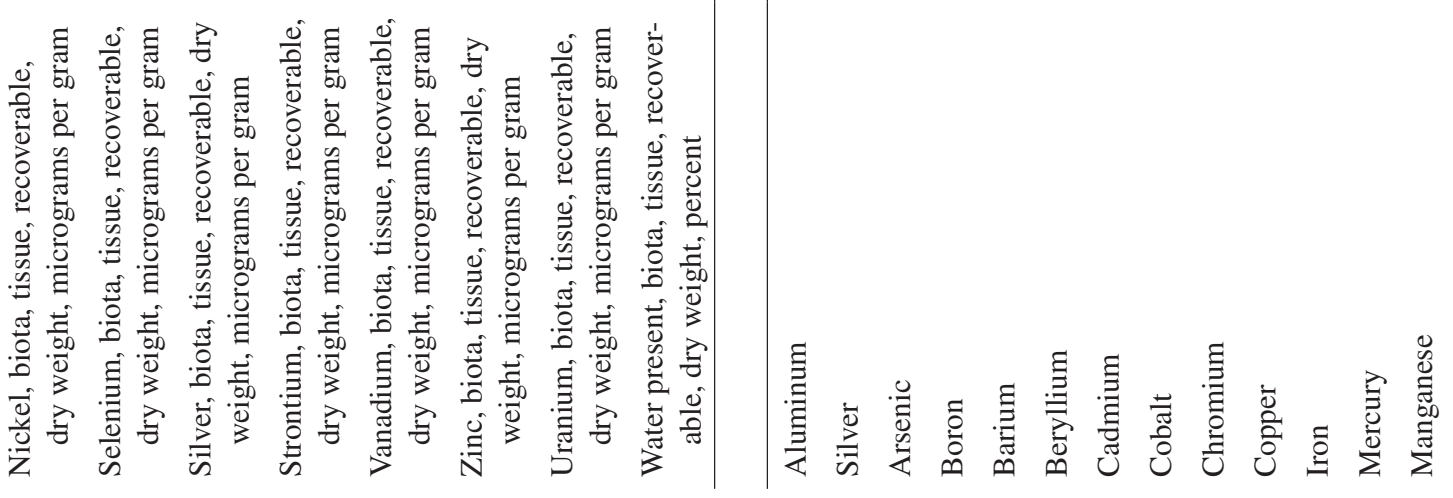




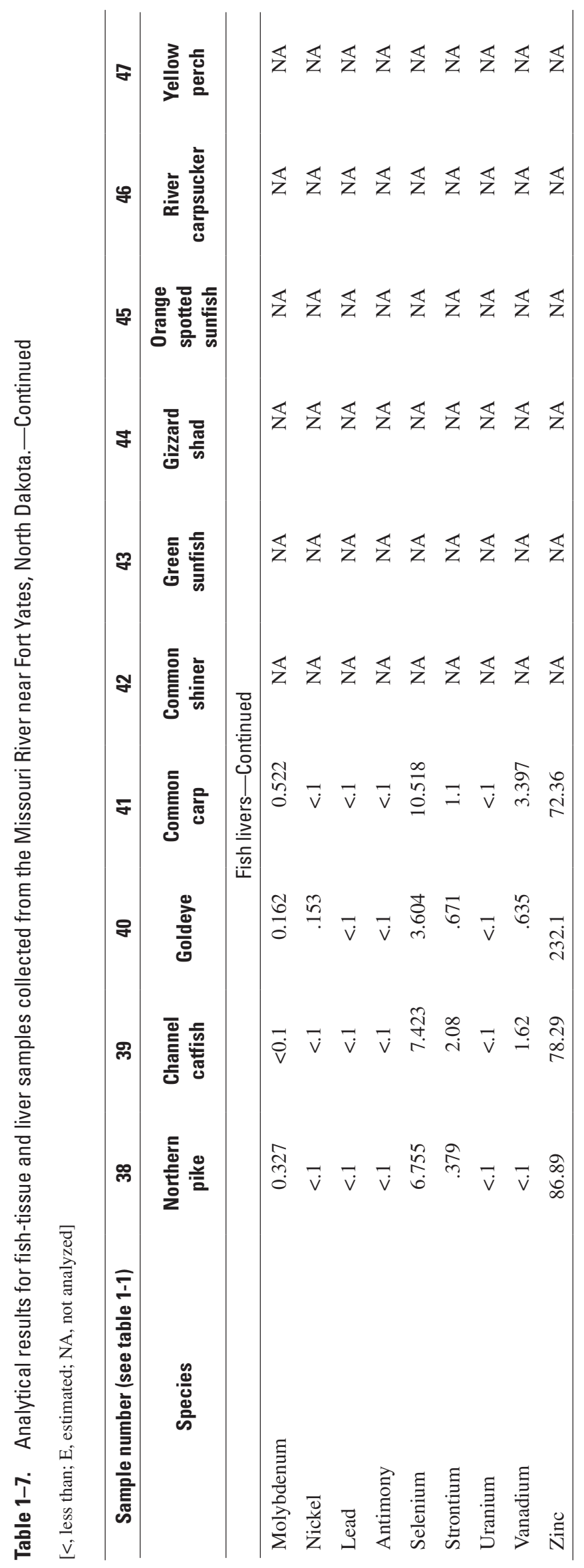


Publishing support provided by:

Helena Publishing Service Center

For more information concerning this publication, contact:

Director, USGS North Dakota Water Science Center

$821 \mathrm{E}$. Interstate Ave.

Bismarck, ND 58503

(406) 457-5900

Or visit the North Dakota Water Science Center Web site at: http://nd.water.usgs.gov 


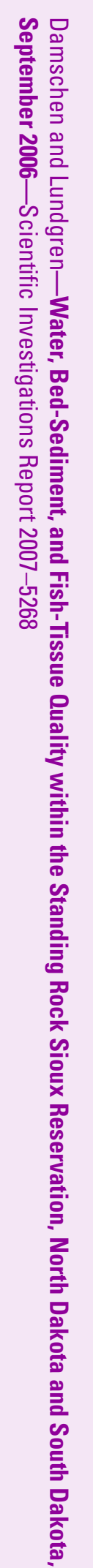

